\title{
Consolidations: Dickens and Seacole
}

Novels can consolidate a sense of belonging and community by introducing readers to a world that appears comfortable and familiar, inhabited by literary characters that feel "like family". ${ }^{1}$ By the mid-nineteenth century, print publications have become an established market commodity that has produced a new class of professional authors, who expanded their influence through serial publications in magazines and public readings. Charles Dickens was at the very forefront of these developments. ${ }^{2}$ Dickens, probably like no other writer before him, made a success of creating such simultaneously broad and relatable figures that bolster the concept of familial feeling and that readers keep returning to fondly to this day. He is at once quintessentially British and one of the first international Anglophone literary bestsellers. Accordingly, the national public sphere is now more than ever intimately tied to a fast-growing transatlantic literary market. Dickens's writing oscillates between a fascination with travel in the increasingly global empire and the safe return to the British home. While his long and highly prolific literary career was shaped by an interest in overseas territories, he had little personal experience of the empire, as Grace Moore (2004: 1) argues. Instead of trying to reconstruct Dickens's views on empire and race throughout his oeuvre, as Moore does, I will, in the following, concentrate on his travelogue American Notes as well as on the topic of philanthropy in Bleak House. ${ }^{3}$ This shows that for Dickens, maybe unexpectedly, his travels to the United States consolidated a 
narrower national understanding of sympathy, as expressed in his "reformist novel" (cf. Claybaugh 2007) Bleak House.

Travelling nurse Mary Seacole also claims a "homely" version of Britishness. Often referred to as the "Black Florence Nightingale", the Jamaican-born Seacole went on a voyage to the Crimea during the war (1854-1856) to take care of British soldiers and rose to considerable fame during her lifetime. In contrast to Dickens, and somewhat paradoxically, she is most successful in her claim to Britishness when she is at the front rather than on the British Isles. It is her eagerness to parade a familiar maternal image abroad that consolidates her version of Black/Creole Britishness which simultaneously boosts national morale and underlines British imperial ambitions. Seacole, whose account is considered one of the earliest first-person narratives of a female Black British subject, understands the literary marketplace as a possible arena for financial compensation for her physical and affective labours. This includes strategically laughing off the racism she encounters. Reading Dickens's texts together with Seacole's Wonderful Adventures as my final couple of entangled tonalities shows a crucial shift in mid-nineteenth-century literature which consolidates British imperialism via "enlightened" differentiation from the Americas and culminates in the more paternalistic rhetoric following the 1857 Sepoy Rebellion. ${ }^{4}$

Preceding these events and immediately following abolition, Britain's global economic and colonial entanglements had shifted away from its lost colony and the West Indies, which were now of decreasing financial importance, to new territories both in Asia and in Africa. Nevertheless, the young United States was, of course, still part of the transatlantic public sphere which, most importantly, shared reading audiences via the English language. With the eventual British outlawing of slavery in its territories in 1833 (taking effect in 1834), US-American abolitionists who still engaged in the struggle against enslavement sought moral support from the "mother country" of old. ${ }^{5}$ So, while the territory of British colonial investments grows, the topic of (American) slavery does not disappear altogether. On the contrary, Victorian writers now frame slavery as that US-American aberration which Britain has long overcome. ${ }^{6}$ This form of British moral exceptionalism that Christopher Brown (2006), as mentioned, describes as "moral capital", is paradoxically understood as an enlightened form of imperialism, which Swaminathan calls a "new ethics of empire" (2009: 212). ${ }^{7}$ 
Both Dickens and Seacole are implicated in these shifts in the literary marketplace, the British renunciation of slavery, and its concomitant growing imperial ambitions. They try to profit from the transatlantic public sphere by evoking a national form of familial feeling. While travelling they construct conciliatory images of home that do not overtly challenge the sensibilities of the British audience. Moreover, with the growing reading public, different genres of prose writing are becoming more established with the travelogue and the novel as popular forms that should be read as part of the rise of the novel phenomenon that, as I have argued, cannot be limited to fictional texts. ${ }^{8}$ In addition to more formulaic sensation novels, repetitive narrative patterns and endings are also becoming outmoded by the demands of readers for more complex realist verisimilitude. Both Dickens and Seacole's texts sit somewhat uneasily in relation to realist conventions of storytelling with Dickens at times wavering between documenting and sentimentalising and Seacole liberally editing out unwanted details. Nevertheless, both display a self-assured and assuring attitude in their narrators and narrative personae. In her travel account, Seacole utilises a confident tone often directly addressing her readers more familiarly than the Black authors before her. She strategically scandalises "Yankee" racism while British prejudice is downplayed. Moreover, she tones down any overtly sexual references in her "adventures". Dickens too uses excessive overt narrative comment to promote an idea of a shared sense of indignation at lacking American manners in his travelogue and at the misguided international philanthropy of Mrs Jellyby in Bleak House. Thus, "fa(r)ther from home", in Dickens we can detect a paternalistic narrative voice that seems to espouse a nationalistic conception of reform, which in his fictional writing is expressed in a tension between sentimentalism and realism. Seacole's Black Victorian maternity, as " $(\mathrm{m})$ Other of the nation", in turn, promotes a humorous portrayal of a potential "Other" (global and imperial) Britishness. Both their consolidating tonalities rest less on complex introspection than on an explicit reassuring British familiarity. However, while Dickens increasingly understands British familial feeling as tied to whiteness, Seacole contests such racialised conceptions of national belonging. 


\section{Fa(R)THer From Home: Charles Dickens's AMERICAN Notes ANd BLEAK House}

In 1842, Charles Dickens spent six months travelling the United States, which for many British authors had become a popular destination. To put it in familial terms, they were curious about the fate of the rebellious offspring of the former colony. While there is a feeling of familiarity not least through the shared English language, gradually, the independent young nation is also perceived as different, in manners, in pronunciation, and in its political outlook. The 1840s are a particularly interesting period in which the consensus in the British public sphere had shifted towards a general condemnation of slavery while the United States remained deeply divided on the issue until after the Civil War. This makes for an uneasy transatlantic bond. In the States, Dickens is initially welcomed as a literary hero with large audiences greeting him and back in England, he quickly publishes his travel account as American Notes for General Circulation in the same year. The subtitle, "for general circulation", was an obvious allusion to the lack of international copyright that made cheap unauthorised editions of British books very popular in the United States at the time and a great concern to authors like him. Accordingly, and to the dismay of the American press, Dickens used his journey for public speeches campaigning for stricter copyrights. Dickens's ambivalent desire to be liked and at the same time not to hold back with critique shapes the tone of the text. Dickens professes that he does not want to upset his readers in the United States-after all a (potentially growing) paying public-but also succumbs to the British convention voiced in travelogues of the time which harshly criticised (the lack of) American manners (cf. Mulvey 1990). His text should therefore be regarded as part of a larger transnational public sphere, as Amanda Claybaugh explains:

Dickens's tour participated in some Anglo-American networks (suffrage and anti-slavery reform) while attempting to regulate another (the literary marketplace). But his travel book shows that social reform and the literary marketplace cannot be separated so easily. (2006: 440)

On occasion, Dickens admiringly describes US-American citizens, institutions, and surroundings, and, at other times, he includes longish, quite defensive comments in relation to what might cause offence in his remarks 
showing the delicate entanglements between the transatlantic networks of reform and literature that Claybaugh mentions.

In the very beginning of the journey, Dickens keeps referring to himself in the third person in full as "Charles Dickens, Esquire" (AN 9) and it seems as if the lack of distance between his private person and the public literary persona and narrator was causing him difficulty in finding the right tone, especially when he was both openly lauded and attacked. The concluding remarks, thus somewhat unconvincingly, try to appease his diverse reading publics by stating:

There are many passages in this book, where I have been at some pains to resist the temptation of troubling my readers with my own deductions and conclusions; preferring that they should judge for themselves, from such premises as I have laid before them. My only object in the outset, was, to carry them with me faithfully wheresoever I went, and that task I have discharged. But I may be pardoned, if on such a theme as the general character of the American people, and the general character of their social system, as presented to a stranger's eyes, I desire to express my own opinions in a few words, before I bring these volumes to a close. (AN 266)

Dickens claims to be an objective witness. Nonetheless, he also insists that he is entitled to his own point of view. Part of this paradoxical assessment, of course, has to do with the perspective of the travelling Englishman explaining the foreign territory and the "general character of the American people" to his compatriots.

One of the most striking experiences of difference in the navigation of public space for Dickens is the unfamiliar greater visibility of non-white people. While British lines of differentiation relied on social stratification and a marginalised servant class, the United States had established a strict system of race segregation which feels alien to Dickens when he describes boarding a train leaving Boston.

There are no first and second class carriages as with us; but there is a gentleman's car and a ladies' car: the main distinction between which is that in the first, everybody smokes; and in the second, nobody does. As a black man never travels with a white one, there is also a negro car $[\ldots]$. The conductor or check-taker, or guard, or whatever he may be, wears no uniform. He walks up and down the car [...]; or enters into conversation with the passengers about him. [...] Everybody talks to you, or to anybody else who hits his fancy. (AN 72-73) 
While racial segregation is strict, the gendered separation of the cars is not exclusive as in "the ladies' car, there are a great many gentlemen who have ladies with them" (AN 72) and Dickens is also surprised that women travel alone. As in Seacole's case, this form of unaccompanied female mobility is eyed with great suspicion by the Victorian. ${ }^{9}$ The general impression that is communicated throughout is a shocking lack of social etiquette. Dickens scolds Americans for their over-familiarity and is appalled by the "offensive and sickening" practice of spitting chewing tobacco everywhere in public, even by senators (AN 125, 137). On the train, Dickens is annoyed by the conductor who interrogates him, "as his fancy dictates" in what he perceives as intrusive questioning, the wrong pronunciation of English, and, most importantly, a disregard for his "place". ${ }^{10}$ Being addressed without the proper decorum by the working people "below" him comes as an unpleasant surprise to the prim Englishman. ${ }^{11}$

During his journey Dickens is certainly guilty of a paternalistic tone ${ }^{12}$ but he also seeks consolidation by complimenting his American hosts profusely at times. Given his interest in social reform, he follows the example of other English authors before him to visit, for instance, a Boston school for blind children (The Perkins Institution, whose description is partly taken verbatim from their Annual Report), a hospital for the "insane", several prisons, and factories. He notes positively what "will startle a large class of readers on this side of the Atlantic" (AN 78), namely, that the female workers in one of the factories have access to a piano, a circulating library, and even publish their own periodical. Dickens comments favourably on the democratising function of literature across "station" and is clearly supportive of crossing barriers of class when the direction is one of "uplift". The lack of manners, on the other hand, is what he perceives as one of the many "degrading” ills of democracy. Dickens's views are therefore often ambivalent, generally distrusting the "Chartist mob", at times demanding individual responsibility but also calling for solidarity with the working class.

However impressed Dickens seems with some of the progressive causes in the States, slavery, "that most hideous blot and foul disgrace" (AN 34), remains the one topic that he cannot dismiss as simply an American "peculiarity". ${ }^{13}$ For him, there can be no reconciliation with the service by people who are "purchased", and he describes his first encounter with being waited on (something he would be more than familiar with) as a feeling of "shame and self-reproach" because of his awareness of the enslavement of the servers: 
We stopped to dine at Baltimore, and being now in Maryland, were waited on, for the first time, by slaves. The sensation of exacting any service from human creatures who are bought and sold, and being, for the time, a party as it were to their condition, is not an enviable one. The institution exists, perhaps, in its least repulsive and most mitigated form in such a town as this; but it is slavery; and though I was, with respect to it, an innocent man, its presence filled me with a sense of shame and self-reproach. (AN 127)

Afterwards, Dickens decides to cut his scheduled journey short and consequently his personal observations at this stage are limited to his admitted but "innocent" complicity with what he perceives as a "mitigated form" of slavery. He muses:

I had at first intended going South-to Charleston. But when I came to consider the length of time which this journey would occupy, and the premature heat of the season, which even at Washington had been often very trying; and weighed moreover, in my own mind, the pain of living in the constant contemplation of slavery, against the more than doubtful chances of my ever seeing it, in the time I had to spare, stripped of the disguises in which it would certainly be dressed, and so adding any item to the host of facts already heaped together on the subject; I began to listen to old whisperings which had often been present to me at home in England, when I little thought of ever being here; and to dream again of cities growing up, like palaces in fairy tales, among the wilds and forests of the west. (AN 140-141)

In this quote, Dickens gives several reasons for his altered itinerary: the long duration of the journey, the suffocating weather, but also the fact that he is now of the opinion that any contact with slavery he could procure, would be shielded from the "ugly" truth, as, in fact, happens during his following failed attempt to visit the slave quarters on a plantation in Virginia. Instead he conjures up his boyish dream of America as the fairytale "wild west", as that innocent landscape (devoid of any connotations of settler violence against the indigenous inhabitants), which he used to indulge in back "at home in England". Interestingly then, Dickens doubts his capacity to become a meaningful witness in the fight against slavery and instead relies on print culture as a form of verification. In addition to his wavering narrator comments, we thus also find the (often uncredited) inclusion of other authors' materials in his travelogue. At first sight this must appear counter-intuitive given Dickens's own campaign for stricter 
copyright. Therefore, before dealing with the rest of his journey, I first discuss the final chapter before the "Concluding Remarks" which was simply entitled "Slavery" and caused far-reaching controversy. ${ }^{14}$

In this strangely isolated chapter in the text, Dickens takes additional space to condemn the "atrocities" of the system of chattel slavery. He refutes American claims that most slave owners treat their slaves well and who argue that "it is not so bad, as you in England take it to be" (AN 251). ${ }^{15}$ The majority of this information is taken from American Slavery As It Is, a 1839 publication by Theodore D. Welt for the Anti-Slavery Society (cf. Brattin 2015; Claybaugh 2007: 75-76). Dickens, for instance, copies a comprehensive list of several pages of advertisements for runaway slaves from the abolitionist text into his own account. However, rather than understand this simply as unauthorised piracy, Giulia Fabi speaks of Dickens's "documentary strategy" in this context:

Intended as identikits to recover lost property, these advertisements are “dialogized" with the abolitionist context of Dickens' argumentation and they become polemical tools to undermine the right to own human property, as Dickens sheds the light of irony on the contradictions between the words of the upholders of slavery and the "pictures" of the slaves that are "drawn ... by their own truthful masters." (1997: 128)

In contrast to his own restricted glimpses at the realities of slavery, Dickens trusts in the written word, which, as Fabi emphasises, paradoxically garners even more credibility coming from the slave owners themselves. Dickens, in including these materials into his narrative, characteristically combines an emotionalising with a documentary impulse. This has a different effect than the (fictional) eighteenth-century sentimental accounts of the "poor African". Against their original purpose to recapture the enslaved (and as Dickens notes appalled, often unashamedly listing the full names and addresses of the slave owners who have committed these atrocities), these advertisements are used by the abolitionists as testimony on the injustice against individual people who almost all can be identified by name. ${ }^{16}$ All beginning with "Ran away", they are: "Caroline", "Betsy", "Manuel", "Fanny", "a negro boy about twelve years old", "Hown" and "Grise, his wife", a "boy named James", "John", "Myra", "a negro woman and two children", "Henry", "Pompey", "a negro man", "Rachel", "Sam", "Dennis", "Simon", "Arthur", "Isaac", "Mary", "Ben”, "Tom", "Ned", "Josiah", "Edward", "Ellie”, "Randal”, “Bob”, "Kentucky Tom”, 
“Anthony", “Jim Blake”, “Maria”, "Mary”, "Fountain”, “Jim”, “John”, "a negro man”, "Mary", “Judy”, “Levi”, "Washington”, “John”, “Sally”, "Joe Dennis", "Jack", and "Ivory" (AN 255-257). Their bodies are described as bearing the marks and scars of the severe physical harm committed against them. This list, Dickens is sure, will sicken and repel his readers (AN 258). He continues by providing a further range of clippings from American newspapers that he collected during his journey and which attest to the ubiquity of violence and crime that Dickens attributes directly to the fact that "the character of the parties concerned was formed in slave districts, and brutalised by slave customs" (AN 258). Once more the "horror" of slavery relates not only to the violence against Black bodies but includes the shocking revelation that it is supposedly "civilised" white people who commit these deeds and who are thus understood to be equally "brutalised" by the system. Dickens is not sentimentalising the fate of one particularly innocent nameless victim (remember Sterne's "poor negro girl") and the fact that he lists several pages of such gruesome descriptions also does not amount simply to a reproduction of "spectacular" scenes of violence (as the infamous scenes of murder and suicide in Behn's much earlier Oroonoko, for instance). Paradoxically, his "plagiarising" and incorporation of other sources can be considered part of an authenticating strategy here. Furthermore, Claybaugh (2007: 75) understands Dickens's reproduction of abolitionist publications as a strategy to "defamiliarize" slavery: Southern newspapers that complain about abolitionist propaganda "constitute a public sphere that has been deformed by a too-familiar violence" (2007: 78). Again, the problem then is not only the harm done to Black people, it is also the degrading effect that the familiarity with slavery has on white Americans. What is more, in "defamiliarizing" American atrocities, Dickens's text also consolidates ideas of British superiority.

Like Seacole after him, Dickens condemns American slavery but often repeats racist prejudice himself. It is obvious that he is both fascinated and repulsed by the, for him certainly unfamiliar, quotidian sight of Black people. In his own travels this becomes apparent in his continued journey through Virginia which is related at the beginning of the second volume of the travelogue. There he describes his "very black" driver in his formal yet patched dress as an "insane imitation of an English coachman!" (AN 148). Dickens dwells on the unfamiliar pronunciation of the man and his supposedly affected gesturing "like a harlequin, rolling his eyes" (AN 150). At this point, similar to his earlier sketches and typical of travel 
writing in general, Dickens is happy to share his impressions of generic (and at the same time intriguingly Other) characters. So, while the system of chattel slavery deeply disturbs him, he also seems hesitant to accept African Americans as anything comparable to civilised Englishmen (or capable of the propriety of English service). Not only Black authors then are belittled for their "imitative art", even the capacity of Black slaves/ servants to procure the "proper social decorum" is negated as "insane imitation". Additionally, Dickens often places African Americans in the literal or figurative dehumanising vicinity of animals, as with the naked "negro children" rolling around "with dogs and pigs" (AN 15l) and the Black drivers who are "chattering [...] like so many monkeys" (AN 147). Thus, although his inclusion of abolitionist materials in the slavery chapter follows a more factual logic, his own perceptions are tainted by preconception. Dickens also falls prey to the temptation to employ an overtly sentimentalising tone, for instance, when he witnesses how a mother is sold off without the father of her children. This scene is described in the sentimental phrasing "the mother was misery's picture" (AN 151). In this instance, Dickens appears more interested in "collecting her picture" as part of his affecting representation, with the severing of family bonds as a longestablished sentimentalist trope of condemning slavery, than her actual fate. ${ }^{17}$

Given the myopia of the traveller, Dickens can only detect fault in the foreign culture that he visits. For him, it is no contradiction to look down upon Black people and yet call out the "horrible institution" that the supposed American champions "of Life, Liberty, and the Pursuit of Happiness" (AN 151) uphold. On the one hand, Dickens almost mocks American pride in their Declaration of Independence; on the other hand, he also tries to be a gracious guest when he praises the owner of the plantation who will not let him inspect the slave dwellings in person as a "considerate and excellent master" and "a kind-hearted, worthy man" (AN 153). At times then, Dickens seems to doubt the authority of his own narrative voice, maybe because of the identification of it with his public persona. ${ }^{18}$ The tone of American Notes therefore rather than successfully consolidating his various reading audiences seems to sit uneasily in the transatlantic sphere with many American readers offended, penning angered critiques. As a result, Dickens thought it necessary to comment in several pre- and postscripts ${ }^{19}$ on his travelogue and its complicated reception. In general, the disgruntled author seems most successful in appealing to the sentiments of his readers on his home ground. During his travels Dickens 
gradually comes to realise that while there is still a transatlantic bond between Britain and the United States, it does not amount to a shared structure of "familial feeling" any longer.

In her comprehensive analysis of Dickens's references to Native Americans in his writing (which like his descriptions of African Americans are equally problematic ${ }^{20}$ ), Kate Flint (2000: 99) emphasises that instead of envisioning Native Americans as childlike "noble savages", it is in fact the independent United States that are infantilised as the "degenerate child" of the Great Fathers of the Revolution in American Notes (AN 269). Dickens demonstrates a nineteenth-century ambivalence that condemned slavery as unnatural but was increasingly embracing civilisational gradations in human "races" that would elevate Europeans to the status of "natural" leaders in a "progressive logic" that easily reconciled ideas of reform with imperial expansion. The United States instead of being raised to this higher status are in danger of being pulled down by their holding on to the "backward" idea of slavery. Accordingly, Dickens criticises the American incapacity to produce a genuinely "healthy" tone of public debate in their national print culture.

In this way, he can also return to the "unprotected" status of American literature in his concluding remarks-again a nod to the unresolved copyrights issue that irks him. It is the "abject state" of public discourse that has a direct impact on what Dickens describes as the "tone of public feeling":

while the newspaper press of America is in, or near, its present abject state, high moral improvement in that country, is hopeless. Year by year, it must and will go back; year by year, the tone of public feeling must sink lower down $[\ldots]$. (AN 269)

The lowly status of the American media thus leads to the current "degenerate" state of the American nation. Cultural refinement requires that public feeling be expressed in the right tone. While Dickens is certain that the United States currently does not live up to the high standard of British morals, it is interesting to note that he himself evidently also struggled to envision the right tone for a transatlantic form of familial feeling. Consequently, American Notes is also the herald of a paradoxical recluse of Dickens. The more mobile he was and the more transnational his reading public became, the more nationalistic his idealised version of the home seems to have become. This influenced his conception of reform in his 
following novels. For Dickens, as Claybaugh contends, "the withdrawal to the nation was what enabled reform" (2007: 84). Ultimately, the home, in the capitalised well-worn nod to the dear English "Home" that defies representation, is acknowledged in the last lines of the travelogue as the true destination of every traveller: "winding up with Home and all that makes it dear: no tongue can tell, or pen of mine describe" (AN 249). ${ }^{21}$ "Fa(r)ther from home", Dickens thus romanticises a domestic version of Englishness. Subsequently, Dickens's growing distrust in transnational networks of reform becomes most obvious in his mockery of Mrs Jellyby in Bleak House with feeling, familiarity, and notions of belonging reimagined as hard-fought for and contested resources.

Published as a series from 1852 to 1853 , Bleak House is a vast portrait of England's social grievances. In close to a thousand pages Dickens starts off with what reads like a family novel that increasingly turns into a detective story. In his preface Dickens famously states, "In Bleak House, I have purposely dwelt upon the romantic side of familiar things" (BH 7). It is the plight of the poor at home, the "dark continent" of urban London, rather than the actual African continent that he is concerned with. ${ }^{22}$ In the following, I am not going to offer a general reading of the novel but rather concentrate on the idealised conceptions of motherhood and the infamous idea of "Telescopic Philanthropy", the title of chapter twenty. The misguided humanitarian Mrs Jellyby fails to acknowledge the misery in front of her doorstep but invests all her energy into her missionary work for Africa, which amounts to time-consuming letter writing and fundraising. This has been linked to the ill-fated attempts in exploring the Niger region in 1841 (cf. Carens 2005: 87-95; Teukolsky 2009), a context that many contemporary readers would still be familiar with.

From the moment the novel's protagonist and part narrator, Esther Summerson, enters the house of the Jellybys she is shocked by the deplorable state of the many children and shabby surroundings. Mr Jellyby seems to have resigned completely to the rule of his wife and in that sense also fails as the Victorian head of the family. The domestic shortcomings of the Jellybys are directly resulting from the continuous prioritising of "Africa" and $\mathrm{Mr}$ Jellyby's silence is characterised as non-English, pushing him in the vicinity with "natives": "As he never spoke a word, he might have been a native, but for his complexion" ( $\mathrm{BH} 57$ ). The oldest daughter Caddy, who confides in Esther, is miserable being exploited as her mother's secretary. Her destiny is tainted, her face and skin literally stained by the ink that she constantly uses to write her mother's letters endangering her 
whiteness (cf. BH 53). Caddy imagines herself time and again as "enslaved" by her mother and her philanthropic projects. Interestingly, the slogan of the earlier abolitionist movement has survived and is now reemployed in the Christian proselytisation of Africa, which makes for strange bedfellows of colonialist expansion and humanitarian claims. ${ }^{23}$ At one point, Caddy bursts out, "Talk of Africa! I couldn't be worse off if I was a what's-hisname-man and a brother!" (BH 217) and she later adds that she will not remain a slave for the rest of her life, stressing that she will not marry a philanthropist (cf. BH 219). Her "enslavement" to the African cause has turned her into a-tellingly male- "man and a brother" and thus also robs her of the ability to embody proper femininity. ${ }^{24}$ After feeling embarrassed by the dirt and lack of decorum in front of Esther during her first visit, Caddy decides to "be improved in that respect" (BH 220) by learning to dance. This is also where she meets her future husband, the pretentious dance teacher Prince Turveydrop whose family embodies the "deportment", so lacking in the Jellyby home.

When Caddy finally announces her plans of getting married in front of her parents, her mother reproaches her with the following accusation: "a degenerate child, when you might have devoted yourself to the great public measure" ( $\mathrm{BH} \mathrm{383).} \mathrm{It} \mathrm{is} \mathrm{only} \mathrm{with} \mathrm{the} \mathrm{help} \mathrm{of} \mathrm{angelic} \mathrm{Esther} \mathrm{that}$ Caddy can finally "emancipate" herself from her tyrannical mother and eventually get married. ${ }^{25}$ Paradoxically then, in the novel's logic, a woman's freedom can be found only in matrimony and not in her engagement in public service. From Mrs Jellyby's ridiculed point of view, this decision against professional duty is "degenerate". This confirms the limited vision of female freedom in Bleak House. Contrary to the familial scheming to "sell" women off on the "marriage market" that is criticised in Jane Austen's novels, Mrs Jellyby shows too little interest in her daughter's domestic success, which also ends in the family's financial ruin (cf. Cain 2008: 145). Unlike other female Victorian heroines, Caddy Jellyby displays no interest in a role that would challenge the image of the angel in the house. ${ }^{26}$

In addition to the reference to the Wedgwood medallion and the already mentioned "native" disarray of the Jellyby household, Bleak House also partakes in the common strategy to superimpose race with class. The dirty slum inhabitant in London is portrayed as literally "blackened" which is why Timothy Carens speaks of an "Africanization of England" (2008: 42) in this context. But instead of dwelling on industry and 
urbanisation at greater length, the neglect of the urban poor in the novel is primarily related to conceptions of failed motherhood:

In Bleak House, the responsibility for contaminating the nation with versions of "the black figure" shifts from captains of industry who exploit their workers to middle-class "mothers of England" who neglect their proper duties. (Carens 2008: 41)

Indeed, the reference to English "black figures" had served as a means to play off reform and abolition against each other for a long time already. What is new in Dickens, however, is a distrust in increasingly specialised networks of transnational philanthropy in which more and more women actively participated. By now, eighteenth-century sentimentalism has morphed into professionalised philanthropy that is not the expression of noble goodwill of the aristocracy but middle-class duty.

In his transnational study of the relationship between US-American and British philanthropy and fiction, Frank Christianson writes, "the rise of modern philanthropy corresponds with the period in the 1840s and 1850s when an identifiable professional class emerged in Britain and the US" (2007: 4). Dickens is highly critical of any form of over-regulation (embodied obviously in the ineffectual Chancery Court in the novel). ${ }^{27}$ Thus, while he is confident about British civilisational supremacy, he vehemently disparages ineffectual management and a morally reprehensible short-sightedness of "the imperial gaze, the philanthropic gaze, [and] the missionary gaze" (Chennells 2000: 164). For Dickens, the domestic sphere is where effectual reform would begin. In this context, D.A. Miller speaks of the "faultiness of the family" (1983: 83) as a symptom of this failed philanthropy in Bleak House. By highlighting shortcomings of familial care, Dickens, Miller argues, strengthens normative conceptions of domesticity. This is connected to

the utilitarianism that Dickens's sentimentality about the family rationalizes rather than resists. The novels continually imply the family's advantages over other agencies in producing acceptable citizens of the liberal state both in quantitative terms as its greater economy-and in qualitative ones as the superiority of the bonds between its members. (Miller 1983: 83)

Miller concludes, “Dickens's vigorous reformism makes better sense as an undeclared defense of the status quo" (1983: 84). In other words, 
Dickens's perspective is one of disentanglement. The nuclear family rather than the state is the locus of true affection and sympathy. Geographically, he recentres London as the starting and ending point of all transnational endeavours (cf. Chennells 2000: 159). Nevertheless, he does not entirely let go of imperial ambitions either. While the Jellyby family is clearly a sign of a corrupted gendered order, men can and should engage in England's colonial missions. ${ }^{28}$ It is specifically mothers like Mrs Jellyby who are at fault and who should take care of the "home front" (cf. Carens 2005: 104-112).

The climax of this lack of the right kind of familial feeling then is the sentimentalised depiction of street urchin Jo, who is not so lucky as to profit from the attention of wealthy middle-class ladies and perishes miserably. He is characterised as follows:

he is not one of Mrs Jellyby's lambs, being wholly unconnected with Borrioboola-Gha; he is not softened by distance and unfamiliarity; he is not a genuine foreign-grown savage; he is the ordinary home-made article. Dirty, ugly, disagreeable to all the senses, in body a common creature of the common streets [...]. ( $\mathrm{BH} 724)$

This narrator description is interesting because it implies that familiarity and closeness in effect prevent fellow-feeling. The unpleasant vicinity to suffering is harder to bear than the supposedly more thrilling adventurous philanthropic projects overseas. Moore argues that Dickens "inverts the dominant discourse by emphasizing Jo's essential 'homeliness' at the same time as registering the paradoxical otherness that renders him a race apart" (2004: 31). Physical closeness is no longer enough to stimulate familial feeling, in fact, it is dangerous as the theme of contagion and Esther's disfigurement as a result of her illness underline. ${ }^{29}$ Accordingly, with the idea of telescoping philanthropy dismissed, Bleak House resorts to a narrower conception of “natural” sympathy that in Dickens's texts often rests on actual familial recognition (in Bleak House, for example, between Esther and her mother Lady Dedlock). Nancy Yousef argues,

Deftly brought together in these scenes of filial recognition are the sentimental hypothesis that natural benevolence is both rooted in and evinced by the affective bonds of family and the Humean idea of sympathy arising from the remarkable resemblance between human beings. [...] Dickens also evokes the idea of similitude as the basis for mutual recognition. (2009: 64) 
In relation to Jo this means that he is radically excluded from this community of familiar objects of "natural benevolence" because of dissimilitude from middle-classness (cf. Yousef 2009: 69). Yousef, however, does not regard this as a shortcoming of Dickens's sentimental scenes but rather understands this as an appeal to reflect on the limits of compassion, a "rendering visible of the overlooked" (2009: 71). In contrast, I would argue, Dickens resorts to a comfortably domestic interrogation of the limits of sympathy. While any sympathy with "natives" or "Africans" is satirically derided, Jo's exclusion in terms of class can be sentimentalised within a larger idealised notion of a yet insufficient national familial feeling of Britishness that is thus also imagined as exclusively white. In contrast to Seacole's more mobile version of Britishness that is inclusive of Blackness, the symbolical Blackness of Jo, is a smudge on his white homeliness. Similarly, Saree Makdisi emphasises that his Blackness is essentially a marker of differentiation: "Ironically, in other words, rather than collapsing London into Africa, what enables the narrator of Bleak House to compare Jo with an African savage is exactly that there is - or ought to be-a sense of difference between the two spaces, the domestic and the foreign" (2014: 200).

This finally brings me more explicitly to the question of tone once more. While Yousef reads Dickens's sentimental scenes as a philosophical challenge to sympathy, they also bear the danger of stifling more radical social criticism. The use of overt narrator comment often provides descriptions of flat character types (as opposed to psychologically complex interiority), especially in the shifts from Esther's voice to the heterodiegetic narrator. Jo's death is recounted by a highly intrusive narrator admonishing the readers across all stations of society: "Dead, your Majesty. Dead, my lords and gentlemen. Dead, Right Reverends and Wrong Reverends of every order. Dead, men and women, born with Heavenly compassion in your hearts. And dying thus around us, every day" (BH 734). In her introduction to Bleak House, Nicola Bradbury singles out this passage as emblematic of the novel's "rhetorical contradictions [...] [which], divided between unmediated feeling and audience manipulation, correspond to the ambivalence which fissures and energizes the whole text" (in $\mathrm{BH}$ xxxiii). While Dickens seems more assured of the authority of the narrator's voice here than in the travelogue, his writing too was criticised for its wavering between earnest social critique and lacking verisimilitude that audiences were expecting of the increasingly realist novel form (regarding the famous spontaneous combustion in Bleak House, for instance). 
Christianson argues that Dickens is aware of these tensions within literary realism and stresses the relevance of the preface once more as a place where Dickens would attempt to reassert authorial control. "Many novels in the period employed the move of using an author's preface to defend or verify the probability if not actuality of certain plot points and testify more generally to the "truthfulness' of the work" (2007: 83).

Thus, neither overtly sentimental scenes nor the humorous satire of the Jellybys is seen as contradicting the impulse of truthfulness. Quite the opposite. Christianson sees "Dickens's satiric treatment of philanthropy $[\ldots]$ not [as] an end in itself; rather, its intention is purgative, to rescue philanthropy from the instrumentalising influence of other modern institutions" (2007: 87). As a novelist Dickens succeeds in weaving together different narrators, different modes, ranging from the satirical to the sentimental, combining the family novel with the suspense of detective fiction that builds on reader anticipation. Accordingly, Miller describes the novel's overall structure in the following terms. It is

the compositional principles of discontinuity and delay that organize the form from within its own structure: not only in the formal breaks of chapters, installments, volumes, but also in the substantive shifts from this plotline to that, or from one point of view or narration to another; and generally in the shrewd administration of suspense that keeps the novel always tending toward a denouement that is continually being withheld. (Miller 1983: 76)

The combination of suspense and sentimentalism is conciliatory because the readers know that Dickens will weave everything together. Following Miller, it is paradoxically the multiplicity of narrative styles and voices that shapes Dickens's consolidating tonality in Bleak House. Both in terms of content and form, Dickens secures a cosy version of domestic Britishness, in which maternal incompetence can often be compensated by benevolent older male characters like Mr Jarndyce. He relies on a "benevolent paternalism" (Moore 2004: 37) as an ordering principle that is sympathetic to the plight of the poor who are excluded from the realm of the familiar and, despite being critical of systemic failures, keeps more dangerous radical ideas that would endanger the middle-class status quo (voiced for instance by the Chartists) at a safe distance.

To summarise, looking at American Notes and Bleak House together one can detect that the increasingly transnational public sphere creates a new form of "compassion competition". The plight of the poor in Britain 
is contrasted with the missionary zeal in Africa that is superimposed with abolitionist discourse (cf. Teukolsky 2009: 491). The dedication of white women to the abolition of slavery and missionary work in Africa is linked to idealised notions of motherhood in this transatlantic triangle of Britain, Africa, and the United States. As Gabriele Dietze (2013) has argued in a comprehensive genealogy of how race and gender emancipation projects in the United States have been shaped from the beginning as being in an analogous and antagonistic relation to each other, there is wide-reaching competition in the increasing demands for universal suffrage at the end of the nineteenth century. Hence, it can come as no surprise when the reader learns that Mrs Jellyby eventually turns to the "woman question" and suffragettes following the disappointing failure of her missionary project (cf. $\mathrm{BH}$ 987). In the depiction of the Victorian mother Jellyby, both political ambitions remain indicators of her deviance. The British debate on women's suffrage only really gains momentum in 1870, the year Dickens dies, and the first unsuccessful Women's Suffrage Bill is introduced to parliament. Dickens's holding on to idealised conceptions of motherhood shows the intricate links between national belonging and gender conformity. While Dickens was clearly in favour of the abolition of slavery during his lifetime, he seems to have been far less convinced of the need to reform the Victorian family ideal. Mary Seacole on the surface, too, seems to uphold these middle-class morals but underneath her heroic motherly persona lurks a more dangerous mobile mixed-race femininity.

\section{(M)Other of the Nation: Mary Seacole's WONDERFUL ADVENTURES}

Following her self-appointed mission in the Crimean War, Mary Seacole found herself in financial difficulties back in Britain. Consequently, she is encouraged to write an autobiography, published by James Blackwood in July 1857 as the Wonderful Adventures of Mrs Seacole in Many Lands. The book sold very well-how well exactly, however, has come under some scrutiny. Helen Rappaport (2005) mentions "only" a second edition and sees Seacole's eventual return to Jamaica in 1859 as a sign that the book was not such a great success after all and that her fame lasted only for two brief years until her travelogue was eventually rediscovered in 1984 (and republished in 2005). ${ }^{30}$ Seacole did, however, travel to London once more where she died and was buried in 1881 . 
Before the Crimean War, Seacole stayed in England only for shorter periods of time that are hardly mentioned in her text-which, as the title suggests, focuses on her "wonderful adventures in many lands", including Panama, Turkey, and Russia. Seacole thus claims the colonial term "adventure", defined by Green as "a series of events, partly but not wholly accidental, in settings remote from the domestic and probably from the civilised" (1980: 23). Her narration of voluntary travel marks her as distinct from the earlier transatlantic writers whose journeys were still intimately tied to the forced passage of the "horrors" of slavery. Setting out from the periphery of the empire to claim such adventures was thus not only uncommon for a woman, especially a woman of colour, it was also highly unusual in terms of the direction of her crossing the Atlantic. Cheryl Fish emphasises the "popularity of the travelogue, a genre with episodic discourse that tends to blur boundaries between truth and fiction, the fantastic and the mundane, and has as its center the construction of a self whose wandering gaze uses the other as a mirror" (1997: 479). This form of construction of the self against an Other appears abundantly clear in Dickens's American Notes but obviously plays out differently in Seacole's navigation of complicated territories of national belonging which also affect the structure of the text.

Generically Seacole's Wonderful Adventures is ambiguous. It is not a novel; but it is also not strictly an autobiography or straightforward travelogue. Despite being an autodiegetic text, Wonderful Adventures includes strong dialogical features (as explained in greater detail in relation to Bakhtin in Chap. 2) that undermine the often-assumed narrative coherence of life writing. Seacole admits to "unhistorical inexactness" (WA 128) that stands in stark contrast to the realistic documentary impulse of Robinson Crusoe's fictional autobiographical account but might thus be in fact more truthful of how human memory works:

I have attempted, without any consideration of dates, to give my readers some idea of my life in the Crimea. I am fully aware that I have jumbled up events strangely, talking in the same page, and even sentence, of events which occurred at different times; but I have three excuses to offer for my unhistorical inexactness. In the first place, my memory is far from trustworthy, and I kept no written diary; in the second place, the reader must have had more than enough of journals and chronicles of Crimean life $[\ldots]$; and in the third place, unless I am allowed to tell the story of my life in my own way, I cannot tell it at all. (WA 128) 
Since the travelogue in general and the Crimean War journal specifically are at this point already well-established (or, as implied, even worn out) forms, Seacole proposes a somewhat more unusual style of telling her story. Seacole mixes elements of the traditional male genre of adventure writing and the picaresque (with its focus on travel across space and social landscape) with verifying strategies of the autobiography by including newspaper articles and letters that testify on her behalf in her project of recognition. This continual referencing of official British praise can be interpreted as part of her dialogical strategy here. ${ }^{31}$ While Seacole is moving from station to station, her implied reading community is wooed in her allegiance to Britain, similar to Sancho's embrace of British culture in his letters.

However, unlike Sancho's displayed literary ambitions as a "man of feeling", Seacole is not so eager to prove her literary merit. Literary references are attributed explicitly to the unnamed editor W.J.S. ${ }^{32}$ Seacole's account builds its fascination entirely on the unlikeliness and idiosyncrasies of its protagonist. By admitting to the limits of her literary knowledge and her many direct addresses to the readers she establishes a much more confidential tone than Dickens's often-times admonishing paternalism in his travelogue. Seacole fashions herself as an eccentric storyteller and a practical maternal healer and she boldly proclaims, "I shall make no excuse to my readers for giving them a pretty full history of my struggles to become a Crimean heroine!" (WA 71). The mobility of war and British global exploits, it seems, become a way for her to inscribe herself into the English national body-and overcome obstacles of racism. Thus, while she does not claim literary authority, her account does partake in narrative constructions of familial feelings of Britishness. Simon Gikandi emphasises that "Englishness is an identity [that] must [be] claim[ed] through gestures of writing and reinvention" (1996: 128), and on the level of Seacole's narrated journey to gain British approval, this certainly holds true.

Seacole's narrative identity construction and the interpretation of her text rely on complex racialised, gendered, and classed norms. But as her narrative demonstrates, such identity categorisations often stand in an affective and indissoluble relationship rather than a matrix of clear-cut intersecting binary categories. Seacole is an example of living "in and out of Englishness", as Gikandi (1996: 126) calls it, and it is an uncomfortable position that includes Black self-authorisation by collusion with the imperial enterprise. This entails most notably the strategic citation of correct gender conventions and an overt belief in the capitalist/militarist British 
nation state. Gikandi critically remarks that Seacole thereby reproduces the "master narrative of mid-Victorian Englishness". He argues:

her narration of Englishness is predicated on an archetypal mid-nineteenthcentury trope-what Williams calls "the new bourgeois ethic of self-making and self-help." The act of writing the self is configured as the establishment, by the colonial subject, of its own discursive space within the master narrative of mid-Victorian Englishness. Seacole clearly emplaces herself in this narrative by valorizing its defining codes-individualism, moral restrain, and public duty. Thus while the title of Seacole's narrative might seem to celebrate the romance of adventure, the meaning of her travel is secured by its larger moral purpose- the self-advancement of the subject and her (public) sense of moral good. (Gikandi 1996: 132)

Consequently, almost all critical responses to her writing address the dilemma of how Seacole's narrative can be understood within a postcolonial framework since her affirmative attitude regarding hegemonic Englishness has caused unease. ${ }^{33}$ Despite the widely held "postcolonial consensus" that Britishness (as well as Englishness) is not a stable identity, the interpretations of Seacole's Adventures repeatedly stress her writing herself into (or as Gikandi has it, "in and out" of) Englishness (in contrast to the later postcolonial paradigm of "writing back" to the centre). As with the earlier Black Atlantic authors, I find it helpful to stress her entanglement in transnational imaginations of Britishness. Therefore, in the following, I am not only interested in the ways in which the colonial subject seeks approval as a means to become legible within metropolitan culture or how in mimicking the English she produces subversive "slippage" (Bhabha 1994: 122), destabilising the notion of a coherent colonial identity (which she undoubtedly does), I also want to enquire into the emotional appeal of the British investment in Seacole's war narrative in the nineteenth century and in Seacole as a historical example of Black Britishness today.

There is an ongoing tendency to stress the exclusion of marginalised subjects from Britishness, thereby reinforcing the notion of a homogenous English national body that can exceptionally "absorb strangers". Of course, there is a hegemonic valorisation of whiteness that marks racialised people as "outsiders". But the hegemonic centre does not exist as a stable entity into which the marginalised seek entrance. It is rather through the inclusion of colonial subjects like Seacole, underlined, for instance, 
through the verve with which the military officials saluted the Black nurse and her connections to the Royal family, that a notion of an inclusive British identity is consolidated. As highlighted repeatedly, part of this progressive identity is the supposedly more enlightened response to slavery in comparison to the United States. The British public can embrace abolitionism and at the same time invest in new forms of global free trade that also help consolidate British interests in the Caribbean. The period following (British) abolition is thus a historical juncture that makes a certain flexibility of the norm necessary. Sandra Gunning insightfully mentions the impact of transnational mobility on class and gender ideologies for "both Seacole and her British audience" (2001: 952) and stresses the "politics of adaptability" that subjects like Seacole seem to inhabit. This renders possible a pluralisation of positionalities regarding race and class - which acquire local and conflicting meanings - in the various settings of Seacole's narrative.

To begin with, Seacole needs to be abroad in order to consolidate her Britishness. There she can claim allegiance with the "mother country" by proving that Britain's Others are Other to her as well. Nonetheless, Seacole is, of course, aware of her assumed mostly white British readership, and dialogicity (which could also be understood as an intratextual expression of entanglement) does not necessitate equality between different voices. Seacole repeatedly addresses the readers directly in the conventionalised appeal to the "sympathizing reader" /"kind reader" as part of her consolidating tonality. ${ }^{34}$ Thereby, she constructs familiarity which the text claims quite literally through the construction of kinship. The intimate character of her account is also due to a conversational tone. However, Innes (cf. 2002: 131) emphasises that even though Seacole's narrative style can be associated with orality, her speech is always represented as standard English in contrast to the non-standard idiom of Americans (and later Irish or Cockney characters). What is more, in her case, this form of familiarity is not an unquestioned given, as in Dickens. Dallmann speaks of Seacole's attempt of drawing her readers "into a complicity with the texts autobiographical persona” (2012: 437).

Seacole's account opens with the customary autobiographical details: "I was born in the town of Kingston, in the Island of Jamaica, some time in the present century. [...] I am a Creole, and have good Scotch blood coursing in my veins" (WA 11 ). ${ }^{35}$ The contemporary term "Creole" that she prefers as a self-identification means in the broadest sense "of Caribbean descent" and is not necessarily connected to "race". Her father was a white 
Scottish soldier and her mother a Jamaican freewoman and healer (possibly mixed-race herself). Her gender and widowed status are aspects that Mrs Seacole, who, in accordance with conventions of female vanity in these issues likes to keep her exact age a secret, stresses. But apart from that, she hardly mentions her marriage. Mr Seacole is referred to only very briefly. Seacole recounts how she apparently could not find the courage "to say 'no' to a certain arrangement" (WA 14) and agrees to marry him; in the same paragraph his failing health and death are briefly reported. In this way, specific moments in the narrative are accelerated, that is, a short segment of the narrative discourse is devoted to a long period of the story. The mixed-race marriages both in Seacole and other Black British authors like Equiano become such notable accelerations. By being hardly mentioned they are inserted into the story, but possibly meant to slip the reader's attention or at least not to draw too much attention. While these kinds of marriages were never illegal in Britain or Jamaica, they were certainly not broadly approved of at that period. ${ }^{36}$

After her mother's death, Seacole is left without her most important family members and travels back and forth between Jamaica and London. In this way, she begins her quest as a travelling woman, "an unprotected female" who had to deal with "the pressing candidates for the late $\mathrm{Mr}$ Seacole's shoes" (WA 16). But she steadfastly resists remarrying as she is building a new identity for herself as a successful nurse-a profession she learned from her mother. She calls herself a "yellow" woman or "yellow doctress" (WA 38) and is determined to make her way by establishing her first British Hotel in Cruces, Panama, to provide maternal hospitality. The "family" as a structure of feeling, based on heteronormative gender norms, is consciously cited by marginalised subjects such as Seacole at a time when the nation state and the family are constructed as increasingly mutually dependent spheres of identity formation. "[L]odging herself within the privileged private seat of familial affection and sentiment" (Poon 2008: 50 ), Seacole must perform a specific feminine and motherly identity as a traveller that highlights her service to the nation. She continuously stresses how the grateful British soldiers eventually call her "Mother Seacole" in the Crimea. She transforms herself in what Paravisini-Gebert calls a "consciously articulated reconstruction” (2003: 73). She gradually achieves an-in the admittedly somewhat worn-out wordplay of the title of this section-overlaying of Other with Mother.

Along her journey, her complexion is, of course, no small obstacle. Nonetheless, Seacole herself liberally voices many of the British racial 
prejudices (both negative and positive) and thereby enhances a feeling of familiarity with her reading audience. Seacole employs a black servant, Mac, and a cook, Francis (whose hair she describes as "wool" (WA 103)); she talks about an acquaintance as "Jew Johnny" (WA 84) (and in the Crimea, Greeks and Turks were addressed generically as Johnny by the British) and calls a Turkish officer "Captain Ali Baba" (WA 97). Her own encounters with racism however are downplayed emotionally, once more accelerated in the story, and often combined with humour or distancing narrative techniques.

Racists are almost always US Americans (whom she often calls "Yankees") rather than British-except for the often-cited London episode in which she recalls her first visit to the capital:

I shall never forget my first impressions of London. [...] Strangely enough, some of the most vivid of my recollections are the efforts of the London street-boys to poke fun at my and my companion's complexion. I am only a little brown-a few shades duskier than the brunettes whom you all admire so much; but my companion was very dark, and a fair (if I can apply the term to her) subject for their rude wit. (WA 13)

Racism is a strange recollection and a street-boys' joke-and she even includes a pun about her companion's complexion. Here, Sara Ahmed's work on the politics of emotion is helpful:

Racism is a pain that is hard to bear. Consciousness of racism becomes retrospective, and the question of timing does matter. You learn not to see racism as a way of bearing the pain. (Ahmed 2010: 43)

Seacole makes herself British by stopping to feel interpellated by racismthis is a retrospective act that finds expression in her memoir. She takes the negative and hurtful affect and turns it into a piece of writing which works to uphold and support the British military and nation state and grants her emotional inclusion into a community. ${ }^{37}$ Seacole elides racism as a misappellation: it is an American misnomer of her British identity, as the following quote demonstrates:

$[\mathrm{M}] \mathrm{y}$ experience of travel had not failed to teach me that Americans (even from the Northern States) are always uncomfortable in the company of coloured people, and very often show this feeling in stronger ways than by sour looks and rude words. I think, if I have a little prejudice against our 
cousins across the Atlantic - and I do confess to a little-it is not unreasonable. I have a few shades of deeper brown upon my skin which shows me related - and I am proud of the relationship — to those poor mortals whom you once held enslaved, and whose bodies America still owns. And having this bond, and knowing what slavery is; having seen with my eyes and heard with my ears proof positive enough of its horrors-let others affect to doubt them if they will—is it surprising that I should be somewhat impatient of the airs of superiority which many Americans have endeavoured to assume over me? (WA 20-21)

The vocabulary of family ties is striking here. Seacole has never been enslaved, but there is a distant kinship in her African heritage that connects her to African American slaves. Moreover, in the same quote she also calls American slaveholders "our distant cousins" which includes her in the group of the British. ${ }^{38}$ This shows Seacole's at least tripartite identification as what one today would probably call Afro-Caribbean Britishness. However, this inclusion is only possible because Britishness is no longer associated with chattel slavery. The earlier inclusive version of a British "our" is momentarily displaced when she mentions "those poor mortals whom you once held enslaved, and whose bodies America still owns". This exclusive British "you" is an acknowledgement of an anachronistic notion of Britishness and its involvement in enslavement. Accordingly, in the present, her anger can be directed entirely at the Americans.

Seacole also recounts how in Panama the Americans celebrate Independence Day and one of the drunken men toasts her declaring: "that Providence made her a yaller woman. I calculate, gentlemen, you're all as vexed as I am that she's not wholly white-, but I du [sic] reckon on your rejoicing with me that she's so many shades removed from being entirely black-; and I guess, if we could bleach her by any means we would- $[\ldots]$ I give you Aunty Seacole!" (WA 49). "Aunty Seacole"-a relative after all-who takes care of the soldiers, needs to be whitened in the American logic. But Seacole is strongly offended by this condescending "offer":

[...] I must say, that I don't altogether appreciate your friend's kind wishes with respect to my complexion. If it had been as dark as any nigger's, I should have been just as happy and as useful, and as much respected by those whose respect I value; and as to his offer of bleaching me, I should, even if it were practicable, decline it without any thanks. [...] I drink to you and the general reformation of American manners. (WA 49) 
Again, these instances relating to racism and slavery are not scandalisedshe carefully qualifies her dislike of American manners as her "prejudice" and even reclaims the offensive $n$-word as preferable to the condescending idea of her being "bleached". While there are parallels to Dickens's scolding of lacking manners (and bad pronunciation, as represented in the direct speech), one must bear in mind that Seacole is not on US territory. Consequently, in contrast to Dickens's more diplomatic remarks regarding his Southern hosts, Seacole finds herself in a more comfortable place to voice her critique of slavery.

Central America is an interesting and highly conflicted landscape at the time of the gold rush as Caribbean descendants of the enslaved, runaway American slaves, the British, and white Americans meet. ${ }^{39}$ These forms of new mobility also influence gendered conventions. Seacole disapprovingly mentions the women who wear male attire thereby causing a certain degree of gender trouble in addition to the racial tensions in Panama (cf. Romero-Cesareo 2001). While she is sure not to be conflated with "those French lady writers" 40 (WA 26) and always emphasises her proper feminine attire - and as an author of an autobiography she is, of course, claiming white and male privilege-these masculine women also bear a certain fascination for Seacole:

the female companions of the successful gold-diggers appeared in no hurry to resume the dress or obligations of their sex. Many were clothed as men were, in flannel shirt and boots; rode their mules in unfeminine fashion, but with much ease and courage; and in their conversation successfully rivalled the coarseness of their lords. I think, on the whole, that those French lady writers who desire to enjoy the privileges of man, with the irresponsibility of the other sex, would have been delighted with the disciples who were carrying their principles into practice in the streets of Cruces. (WA 26)

Gender, race, and sexuality (with heterosexuality always endangered by the spectre of female masculinity) are interrelated here. The white female traveller, situated between different national contexts, can assume familial and gender liberties that other women cannot. ${ }^{41}$ Seacole, in contrast, needs (and is eager) to display proper femininity. The "Yankees", and the masculine women in particular, become her foil against which she can imagine herself and become readable as a refined British subject and embodiment of femininity (cf. also Innes 2002: 134). 
It is specifically the "disagreeable" ladies from the Southern United States who are the recipients of her aloof indignation, and who, in Gorgona, are more reliant on her goodwill than she is on theirs:

Indeed, the females who crossed my path were about as unpleasant specimens of the fair sex as one could well wish to avoid. With very few exceptions, those who were not bad were very disagreeable, and as the majority came from the Southern States of America, and showed an instinctive repugnance against any one whose countenance claimed for her kindred with their slaves, my position was far from a pleasant one. Not that it ever gave me any annoyance; they were glad of my stores and comforts, I made money out of their wants; nor do I think our bond of connection was ever closer; only this, if any of them came to me sick and suffering (I say this out of simple justice to myself), I forgot everything, except that she was my sister, and that it was my duty to help her. (WA 51 )

Seacole heroically overlooks their small-minded "repugnance" at her complexion, which is "kindred with their slaves", to demonstrate at once her smart capitalist spirit but also emphasising her humanitarian duties as a healer and their "sister" in the face of illness. On her journey back from the island Gorgona, she suffers yet another "instance of American politeness" (WA 55) when two American women refuse to travel on the same boat with her and her servant girl, Mary, at whom they hurl verbal abuse and Seacole spares the British no details of the American insolence: "I cannot help it if I shock my readers; but the truth is, that one positively spat in poor little Mary's frightened yellow face" (WA 56). Seacole is forced to leave the American ship and board the next British vessel that takes her back to Jamaica. The space of the British ship emotionally links her two "homes". Racism thus in her narrative becomes a strange "recollection" that, while present in Britain too, is often confined to the space of the Americas.

When in 1854 the conflict in the Crimea eventually breaks out, it becomes a global news item in the transatlantic public sphere. In this context Rupprecht emphasises the "cultural history of globalisation" with the "technologised spectacle" of the Crimean War inhabiting a central role in transnational communication (2006: 200). Already the emergence of modern imperial nation states is thus much more globalised than contemporary accounts often acknowledge. The war is accompanied by a new form of immediate correspondence which reported the widespread 
mismanagement and inadequate medical provisions for the troops (Dickens also followed these accounts which fuelled his anger at incompetent bureaucracy). It also turns into an opportunity for Seacole. Paradoxically then, it is the military conflict far away from the British Isles that finally is her chance to demonstrate her belonging to the "mother country" and Seacole can cement her role as mother to the British soldiers, to "be useful to my own 'sons,' suffering for a cause it was so glorious to fight and bleed for" (WA 71). Initially, British authorities reject "the offer of a motherly yellow woman to go to the Crimea and nurse her 'sons' there" (WA 72). Seacole appears quite understanding at first, but is intrigued when she is not accepted as an official nurse: "Was it possible that American prejudices against colour had some root here?" (WA 73). Quite strategically again, British racism does not really count and continues to be referred to diminutively as "American prejudices". Hawthorne argues that "Seacole conducts this questioning of Victorian racial fairness through an intimate dialogue with her reader" (2000: 320). In contrast to Dickens then, who also posits British superior manners, Seacole has to remind her Victorian readers to actually live up to this ideal.

Eventually, she opens her own independent second "British Hotel" and here "Florence Nightingale enters Seacole's text both as the 'real' presence and as a 'site' that Seacole cannot inhabit" (Paravisini-Gebert 2003: 76). ${ }^{42}$ In the Crimea, she has to face her white mirror image Nightingale. And while she is sure not to deny Nightingale's achievements, she also tries to position herself as possibly the better war hero who works much closer to the trenches. Gunning (2001: 973-974) understands this as a tactic of bonding with the working-class soldiers' wives who accompanied the regiment and were also excluded from the traditional image of the neat white feminine middle-class nurse. On the one hand, the British middle-class reading public is challenged regarding the limits of inclusiveness, on the other, the colonial relation is described, once more, as "familial and affective; not shaped by racism" (Salih 2004: 183). The relationship between the older Black woman and the younger white British soldiers is marked as maternal throughout: they are "her sons", she is their "mami". ${ }^{43}$ In the Crimea, Salih concludes, "maternity and militarism seem entirely compatible" (2004: 184).

However, there is one episode in the sick wharf of Balaclava in which Seacole recounts how a dying soldier mistakes her for his wife and squeezes her hand (cf. WA 89), and this is the only mention of a possibly illegitimate touch. Gunning emphasises a difference here between the 
“desexualized U.S. image of the black mammy" (2001: 954) and the role of surrogate mother, sister, and wife that Seacole performs who would also evoke the stereotype of the Caribbean mix-raced "hotelkeeper welcoming male attention" (2001: 971). Seacole refutes this stereotype by emphasising her "service to the brave British army" as "doctress, nurse, and 'mother"' (WA 110). In these instances, her displayed narrative sexual naiveté consolidates her respectability (cf. Dallmann 2012: 434). McMahon explains: "Paradoxically, discursive maternity desexualizes Seacole even while emphasizing her femaleness, lending respectability to her presence among the many men with whom she constructs longstanding, intimate, but discursive bonds of kinship" (2008: 191). Motherhood becomes the perfect vessel of claiming a caring version of familial feeling in which Seacole is not considered Other and yet does not embody the threat of too intimate interracial sexuality.

Following the unsatisfactory resolution of the military conflict and the insight that peace would cause her financial ruin, Seacole decides to travel for a bit in Russia before her eventual return. Here she is presented as an English lady before the Russians and she remarks, "I wonder if they thought they all had my complexion" (WA 161). In the Crimea at least, she has finally fully entered the British family which finds its amusing climax when the soldiers try to pass her off as the Queen or at least a cousin of the monarch.

My companions were young and full of fun, and tried hard to persuade the Russians that I was Queen Victoria, by paying me the most absurd reverence. When this failed they fell back a little, and declared that I was the Queen's first cousin. (WA 162)

In this context, Angelia Poon considers the role of humour and irony in Seacole's failure to perform a proper English body and stresses performative aspects of Seacole's adoption of an English identity. While the distancing function of humour does indeed shape the narrative and its consolidating tone, especially in relation to the attenuation of racism, I do not think that the vocabulary of theatre and "playful performance" (Poon 2008: 73 ) is very helpful here. In her attempt to create an affective mode of belonging to the British family, Seacole's identity construction is neither voluntary play, nor simply a joke. It is also important not to mistake Seacole as a colonial subject caught in "false consciousness" or naïve philanthropy. She is an entrepreneur who managed to make the disdained 
occupation of the "sutler", who was accused of taking financial advantage of military conflict, into a "noble profession" as the special correspondent of The Times William Howard Russell confirms in his opening note "To the Reader", which is included in the text.

Despite Seacole's eventual financial losses, there is a spirit of capitalism here that is based on emotional ties. After all, she sells the British goods to the soldiers to make them $\mathrm{feel}$ at home. Similar to Dickens's travelogue, the "English home" is also an important reference point in her narrative:

Don't you think, reader, if you were lying, with parched lips and fading appetite, thousands of miles from mother, wife, or sister, loathing the rough food by your side, and thinking regretfully of that English home where nothing that could minister to your great need would be left untried-don't you think that you would welcome the familiar figure of the stout lady whose bony horse has just pulled up at the door of your hut, and whose panniers contain some cooling drink, a little broth, some homely cake, or a dish of jelly or blanc-mange $[\ldots]$.

I tell you, reader, I have seen many a bold fellow's eyes moisten at such a season, when a woman's voice and a woman's care have brought to their minds recollections of those happy English homes which some of them never saw again; but many did, who will remember their woman-comrade upon the bleak and barren heights before Sebastopol.

Then their calling me "mother" was not, I think, altogether unmeaning. I used to fancy that there was something homely in the word; and, reader, you cannot think how dear to them was the smallest thing that reminded them of home. (WA 111-112)

In the many repetitions of the word "home" and interjections addressing the reader, Seacole describes herself as a "familiar figure" and "womancomrade" once more emphasising her maternal role. ${ }^{44}$ She not only makes up for the official shortcomings of the nation in taking care of its soldiers, she can also procure specific English culinary delights that are reminiscent of domestic nostalgia. Amy Robinson links this cashing in on familial sentimentality to the rise of consumerism and calls Seacole a "surrogate 'mother" and "a substitute object for the white 'Mother" (1994: 548). Thus, motherly care increasingly is also not simply a "natural" given, it is closely intertwined with capitalism.

Nicole Fluhr regards this as an instance in which the supposedly separate gendered spheres of familial care and capitalist profit can no longer be neatly divided. 
Seacole did not charge for her nursing, but she was paid for food and the medicines she stocked or, in many instances, prepared herself. Because Seacole labels this work "maternal," mothering appears in Wonderful Adventures as public labor-or rather, as labor that bridges the divide between public and private. (2006: 105)

As a travelling woman of colour Seacole intervenes into idealised versions of Victorian femininity that Dickens imagines as safely restricted to the space of the home. And while Gunning and Robinson argue that Seacole becomes a substitute for white motherhood, McMahon claims that Seacole literally embodies the ideal of English femininity that needs to be protected by projecting herself at the centre of the British family (cf. McMahon 2008: 191). She argues,

Seacole invokes both the emotional needs of the troops and the cultural construction of "home" as sacred space, as the very reason for which nations go to war. In doing so, she is able not merely to align herself with the women left in England, but literally to embody English femininity and to stand as a symbol of the home, hearth, and empire for which England was supposedly fighting. (McMahon 2008: 189)

In contrast to Dickens's resistance to accept familiarity across physical differences, Seacole underscores time and again that the soldiers fully accept her as family. Comparable to Dickens, Seacole posits maternal care as a familial alternative to inefficient bureaucracy, but unlike him, "Seacole thus makes patriotic national identity and the domestic characteristics that comprise English motherhood into traits accessible to both whites and nonwhites" (Om 2014: 86).

Seacole ends her account with her return to England as a poor woman and closes her "egotistical remarks" (WA 170) with reference to the "Seacole fund" that was established by a number of high-ranking military men to aid her. The publication of "Seacole's documentary deference to the newly envisioned military thus played directly to the cultural imaginaries that helped to shape dominant metropolitan interpretations of the Crimean War" (Rupprecht 2006: 195). Seacole's narrative functions at the interstices of establishing Britain as an enlightened colonial power that has refuted the "horrors" of slavery and moves into a new phase of imperialism. The docile colonial subject who is an ally in this transition becomes a welcome fantasy to emotionally invest in. At this moment in time, to 
support Seacole was a sign of British solidarity and national pride. As mentioned, her book is published in 1857, the year of the so-called Indian Mutiny/Sepoy Rebellion, which led to the establishment of direct rule over India as a colony, after all.

In response to news of the "Mutiny" and according to reporting in The Times, Seacole had planned to continue her loyal service to the Crown and wanted to support the British army once more in India. But these plans never panned out (cf. J. Robinson 2005: 179-180). This probably most traumatic event in the history of the empire deflects from the Americas and gestures to yet another colonial Other, namely the "ungrateful rebellious Oriental Other" in India. ${ }^{45}$ The so-called Sepoy Mutiny also seems to have aroused a more conformist response from Dickens. Moore writes, "between 1854 and 1857 his [Dickens's] view of the state of the nation had become entangled with his anger at overseas crises, firstly in the Crimea and, more dramatically, in India in 1857" (2004: 3). Both Seacole and Dickens are thus entangled in their consolidating tonality that is shaped by public disdain for American slavery and growing support for the British empire. ${ }^{46}$

The metaphorical British family extends into the various regions of empire and therefore the Mutiny is regarded as a treacherous act within the family. The rebellious "children" must now be placed under imperial/ parental supervision. Keith Booker explains that, rather paradoxically, the British nostalgia for "innocent rule" justified the establishment of more colonial control. ${ }^{47}$ In this context the inclusion of Seacole into the realms of the family also means that the Black woman nurses Britain's hegemonic self-understanding post-Mutiny. Nevertheless, the endorsement of Seacole can also be understood as at least testing British notions of homogeneity. Home and empire are interrelated, and Gunning argues that the "voluntary servitude" by colonial subjects such as Seacole also highlights the feebleness of the mostly male English Caribbean colonial rulers who appear "constitutionally incompatible with their West Indian empire" (2001: 962).

Seacole and her willingness to travel to India is also a reference point for Anthony Trollope who mentions having met her sister in Jamaica in his 1859 travelogue The West Indies and the Spanish Main. This goes to show that white authors were keen to demonstrate their worldliness by discussing their encounters with those few Black people who might be familiar to a larger British reading audience. Trollope writes, 
I took up my abode at Blundle Hall, and found that the landlady in whose custody I had placed myself was a sister of good Mrs. Seacole. "My sister wanted to go to India," said my landlady, "with the army, you know. But Queen Victoria would not let her; her life was too precious." So that Mrs. Seacole is a prophet, even in her own country.

Much cannot be said for the West Indian hotels in general. By far the best that I met was at Cien Fuegos, in Cuba. This one, kept by Mrs. Seacole's sister, was not worse, if not much better, than the average. It was clean, and reasonable as to its charges. I used to wish that the patriotic lady who kept it could be induced to abandon the idea that beefsteaks and onions, and bread and cheese and beer composed the only diet proper for an Englishman. But it is to be remarked all through the island that the people are fond of English dishes, and that they despise, or affect to despise, their own productions. They will give you ox-tail soup when turtle would be much cheaper. Roast beef and beefsteaks are found at almost every meal. An immense deal of beer is consumed. When yams, avocado pears, the mountain cabbage, plaintains [sic], and twenty other delicious vegetables may be had for the gathering, people will insist on eating bad English potatoes; and the desire for English pickles is quite a passion. This is one phase of that Jove for England which is so predominant a charatceristic [sic] of the white inhabitants of the West Indies. (1859: 21)

In his generally condescending and often racist remarks towards the inhabitants of the Caribbean, Trollope repeatedly mocks women, but when confronted with Seacole and her sister, he is at a loss. "Good Mrs. Seacole" has become sacrosanct, "a prophet, even in her own country". Instead Trollope resorts to criticising Seacole's sister's wrong assumption about English culinary preferences. Englishness is created in travelling abroad, but the colonial presence has already manifested itself in preconceived notions on what Englishness actually entails. Seacole and her sister assume as natural a knowledge of English mores, as travellers like Trollope assume "natural" superiority. Familiarity in some ways becomes the wedge between hierarchies of self and Other that become less clear-cut as Black women become English war heroines and white inhabitants of the West Indies insist on "on eating bad English potatoes". ${ }^{48}$ In the colonial encounter there is an entangled affective relationship at work (which is not to say that there are no imbalances in power).

In the famous Punch cartoon Seacole is depicted as standing at the bedside of an invalid soldier, holding up a copy of Punch (Fig. 5.1). 


\section{OUR OWN VIVANDIÈRE.}

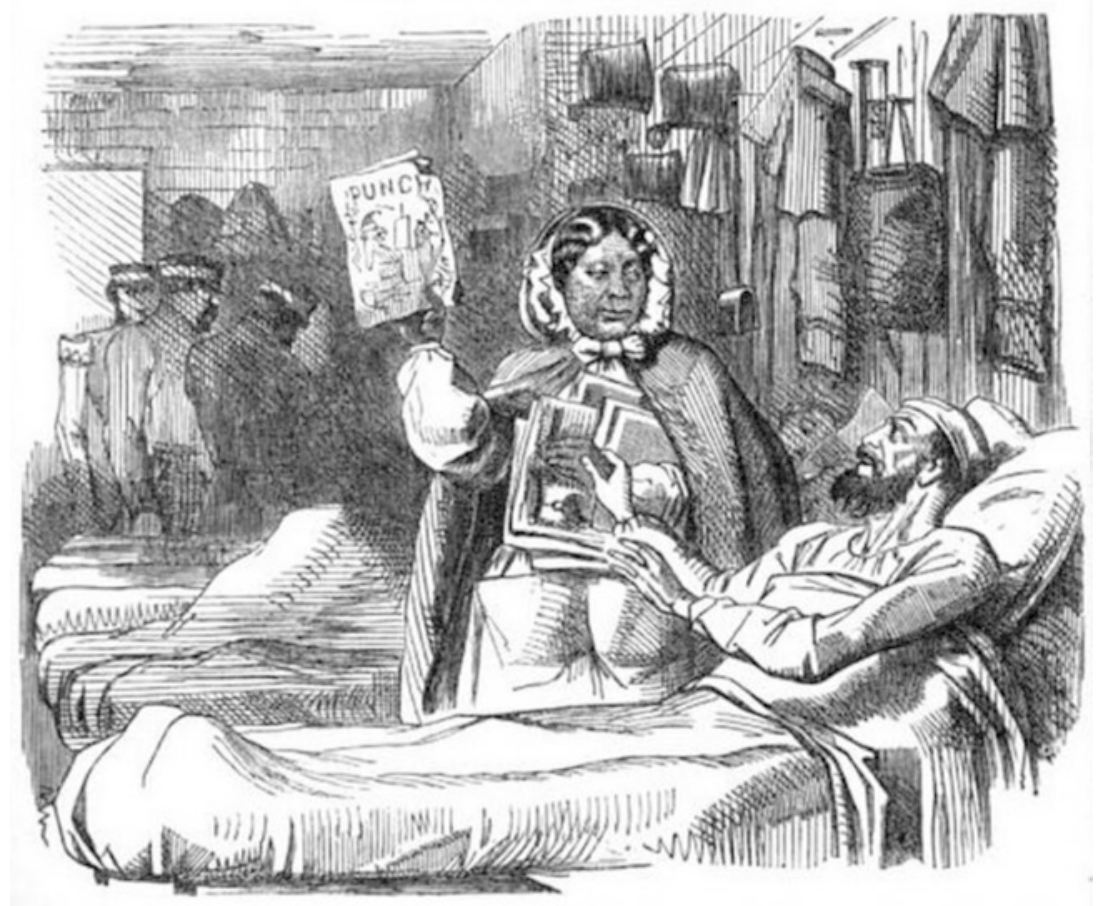

Fig. 5.1 Cartoon depicting Mary Seacole in Punch (London, 30 May 1857)

The white soldier reaches out to hold on to the hand of the Black nurse, and the heading reads: "Our Own Vivandière". The British are in need of a colonial subject such as Seacole, she is their "own". There is gain in claiming Seacole for England. Yet, the contemporary letters in The Times (reprinted in WA 173-177) still read her predominantly as a "Creole" or "Jamaican" rather than as a British woman. As Russell states in his opening note "I trust that England will not forget one who nursed her sick" (WA 5). While there is a dependency on her consolidating skills, she is still not entirely part of that community. In this sense, Amy Robinson (1994), who stresses Seacole's exceptional status, is right. But I would add that it is exactly the movement in a direction of inclusion of Seacole that caters to 
Britain's notion of its own exceptionalism (and this form of exceptionalism becomes a defining feature of modern national identity that needs to be consolidated in a demarcation of Others). Seacole is not only an extraordinary case of Black Britishness, she is also an important signifier for the inclusiveness of the British. The attention to Seacole by her contemporaries underlines the empire's need to be approved of by those it ruled to cement the myth of "just rule". It seems that it is those subjects who still lend themselves most favourably to contemporary constructions of Black British history.

There are at least three waves in the reception of Mary Seacole. Following the Crimean War, Britain celebrated her as a colonial war hero and a noteworthy personality. In the 1980s, Britain started exploring and re-defining its Black history in relation to rediscovered authors and texts. In the third and cotemporary phase the legacy of subjects such as Seacole becomes crucial for the politics of remembering the British slave trade sparked by the bicentennial of the abolition of the slave trade in $2007 .{ }^{49} \mathrm{It}$ is this tradition of qualifying the British as exceptional in their moral response to slavery while remaining strongly anchored in a capitalist logic that turns Seacole into the "perfect" Black Briton. For the politics of remembrance, the contemporary appropriation of early Black Britons also bolsters a retrospective construction of Britishness as "always already multicultural". By now, as Sara Salih (2004) points out, Mary Seacole herself has become a trademark for Jamaicans, nurses, and Black Britons. She was voted "greatest black Briton" in a 2004 poll that came in response to the BBC's Great Britons debate, which had been won by Winston Churchill but had no Black people in the top 100 (cf. Rupprecht 2006, 202-203). ${ }^{50}$ The national politics of remembrance of Britain are remarkable here, aligning one hero of war with another.

Both Seacole and Dickens thus appear as ideal candidates to showcase a fatherly benevolence and motherly caring literary persona. Their tone of address can be characterised as consolidating Britishness. Dickens seems genuinely baffled that his candid remarks regarding American manners should stir controversy. His paternalistic admonishing tone of his travelogue appears more precarious in the growing transatlantic sphere and so it is the safety of the English home that his satirical depiction of telescopic philanthropy in Bleak House conjures up. There is also a safer distance between the fictional narrators and the historical persona in the novel. Seacole, in contrast, uses her Adventures to construe a heroic maternal Britishness that seems to work best when she advertises her British goods 
abroad rather than when she actually is in Britain. Consequently, while Dickens consolidates a version of reform that is limited to the closeness of the home/nation, Seacole imagines Britishness as at once welcoming of Otherness and expansive in global reach. Her overt narration is strategically empowering and diminishes the effects of racism (often via humour). Both Dickens and Seacole therefore added to the Victorian family ideal which, in the course of the nineteenth century, became at once parochial and grandiose in its global imperial ambitions. As the disputed status of Seacole's legacy within British memorial culture demonstrates, the familiarity of belonging to Britain continues to be contested and reconstructed to this day.

\section{Notes}

1. An earlier shorter version of the reading of Seacole has been published previously and is reproduced with permission of WVT: Haschemi Yekani, Elahe. 2012. (M)Other Seacole's Wonderful Adventures: The Politics of Imagining the British Family. In Anglistentag 2011: Freiburg. Proceedings, ed. Monika Fludernik and Benjamin Kohlmann, 339-351. Trier: WVT. Earlier and much shorter versions of both readings of Seacole and Dickens have been published previously and are reproduced with permission of De Gruyter: Haschemi Yekani, Elahe. 2016. Feeling Modern: Narratives of Slavery as Entangled Literary History. In The Humanities between Global Integration and Cultural Diversity, ed. Hans G. Kippenberg and Birgit Mersmann, 117-134. Berlin: De Gruyter. DOI: 10.1515/9783110452181-009.

2. Cvetkovich explores the rise of the so-called sensation novel as part of the larger nineteenth-century expansion of print culture that makes publications more accessible and wide-reaching: "Although circulating libraries and serial publication were already prevalent in the eighteenth century, between 1820 and 1860 there was a massive rise in the number of periodicals that published novels in serial form. The price of these publications, as well as the price of novels issued in book form, dropped considerably, making it possible for the reading material aimed at various different classes to sell in far greater numbers. The spectacular success of Dickens's novels, beginning with the serial publication of The Pickwick Papers in 1836, demonstrated that cultural production could be a profitable endeavor; however, the critics worried about the effects of mass publication on literary quality" (1992: 16).

3. In the following, quotes from the primary sources American Notes for General Circulation (Dickens 2000 [1842]), Bleak House (Dickens 2003 
[1852-1853]), and Wonderful Adventures of Mrs Seacole in Many Lands (Seacole 2005 [1857]) will be abbreviated as AN, BH, and WA respectively in all in-text citations.

4. Even though Seacole and Dickens were contemporaries and Dickens is extremely invested in the publications accompanying the Crimean War (cf. Moore 2004: 75-90), I could not find any explicit acknowledgement of their knowing of each other or each other's texts.

5. This transatlantic exchange produces literary bestsellers on both shores, such as Harriet Beecher Stowe's Uncle Tom's Cabin (1981 [1852]), and leads to Frederick Douglass's travels to Britain in the 1840s (cf. Cooper 1996: 205).

6. Swaminathan sees this discourse indebted to the late eighteenth century, when, as a result of the American Revolution, "Writers in Great Britain pointed to the duplicity of the Americans who spoke of liberty and practiced slavery" (2009: 94).

7. Brantlinger influentially argued that predating the "New Imperialism" of the 1880s (culminating in the so-called Scramble for Africa), the myth of the "dark continent" was used to justify steady colonial expansion beginning already in the 1840s and 1850s. It is this context of the rise of the new imperial ideology that is still connected to abolitionist discourse in midnineteenth-century Victorian England that I discuss in this chapter. Brantlinger writes, "Paradoxically, abolitionism contained the seeds of empire. [...] [A]bolition was not purely altruistic but as economically conditioned as Britain's later empire building in Africa. [...] Britain could afford to legislate against the slave trade only after that trade had helped provide the surplus capital necessary for industrial takeoff. Britain had lost much of its slave-owning territory as a result of the American Revolution; as the leading industrial power in the world Britain found in abolition a way to work against the interests of rivals who were still heavily involved in colonial slavery and a plantation economy. [...] Applied to Africa, however, humanitarianism did point insistently toward imperialism. By the $1860 \mathrm{~s}$ the success of the antislavery movement, the impact of the great Victorian explorers, and the merger in the social sciences of racist and evolutionary doctrines had combined, and the public widely shared a view of Africa which demanded imperialization on moral, religious, and scientific grounds. It is this view I call the myth of the Dark Continent [...]" (1988: 174).

8. Claybaugh who analyses the intertwined Anglo-American public sphere emphasises the Victorian appetite for travelogues: "more than two hundred British men and women published accounts of their travels in the United States during the first half of the nineteenth century, and an equal 
number of men and women from the United States published accounts of their travels in Great Britain” (2007: 5).

9. Later in Canada, Dickens is also intrigued by a cross-dressing woman (AN 227). Greater mobility and changing gender conventions are thus interlinked. Seacole too notes how more and more travelling women adopt male dress. However, from her, already precarious, position as a travelling woman of colour, she is always eager to reassure her English readers of her proper feminine attire.

10. Dickens at one point also complains about how men and boys surround his carriage to stare at and even touch him (cf. AN 127-128). The famous visitor cannot simply observe anonymously, he is part of a new spectacular transnational celebrity culture.

11. Christopher Mulvey emphasises the conventionality of the "genteel tone" of the travel literature of the time: "Literary decorum demanded that an author assumed a refined genteel voice in order to address society. The writer's written voice might be several tones more refined than the writer's spoken voice. The writer-travellers were therefore obliged to adopt a tone of voice which suggested very often that they were of a higher social standing than that to which their actual incomes or birth might otherwise entitle them" (1990: 8). This eagerness to appeal to a cultured gentlemanly English ideal shapes part of what I describe as Dickens's consolidating tonality.

12. While Dickens, as mentioned, claims in the concluding remarks not to want to trouble his readers with his "own deductions and conclusions" (AN 266), statements like the following show an open disdain for lack of personal hygiene that many American readers must have found offensive: "In all modes of travelling, the American customs, with reference to the means of personal cleanliness and wholesome ablution, are extremely negligent and filthy; and I strongly incline to the belief that a considerable amount of illness is referable to this cause" (AN 175).

13. In response to Dickens's damnation of slavery, many Americans in turn criticised Britain's own lack of reforming the conditions of the working class and Irish migrants as Moore explicates (cf. 2004: 49-50). Dickens, like other travellers, refutes these analogies although he himself will resort to similar strategies later in Bleak House.

14. There was even an attempt to ban the book in South Carolina because of its disregard of a law that forbade white men to agitate against slavery in print (cf. Ingham's introduction in AN xxvii).

15. Since the slave trade had been outlawed internationally, the system of chattel slavery was under pressure to "reproduce" slave labour on the plantations. Dickens condemns three types of slave owners: moderate ones that "inherited" their slaves and treat them well, those who buy and "breed" 
slaves and deny any harm, and those who cannot endure the notion of equality and want to be served.

16. This testimonial approach to list the names of individuals who escaped enslavement could even be compared to the contemporary strategy of Black Lives Matter activists who demand that we "say their names" to recognise the humanity of those dehumanised by ongoing police brutality against African Americans which, many believe, has its root in America's history of chattel slavery.

17. Valerie Purton discusses Dickens in the context of "the sentimental tradition" (2012). She argues that where Sterne fostered ambivalence, Dickens kept the sentimental and humorous apart. American Notes includes several "typical" sentimental scenes, for example, when Dickens describes a German prisoner in Philadelphia, again in terms of a heart-rending "picture of forlorn affliction": "The taste and ingenuity he had displayed in everything were most extraordinary; and yet a more dejected, heartbroken, wretched creature, it would be difficult to imagine. I never saw such a picture of forlorn affliction and distress of mind. My heart bled for him; and when the tears ran down his cheeks, and he took one of the visitors aside, to ask, with his trembling hands nervously clutching at his coat to detain him, whether there was no hope of his dismal sentence being commuted, the spectacle was really too painful to witness. I never saw or heard of any kind of misery that impressed me more than the wretchedness of this man" (AN 114-115).

18. Dickens is annoyed when an American traveller identifies him as his literary alter ego Boz (AN 219). Thus, while bathing in fame as a celebrated author and public speaker, Dickens also reaps the more uncomfortable aspects of this new transatlantic celebrity culture.

19. There are the mentioned "Concluding Remarks" that follow the chapter on slavery, there is also an unpublished Introduction from 1842, Dickens's 1850 Preface to the cheap edition as well as a Postscript to the 1868 Library edition.

20. In relation to the Native Americans Dickens encounters on his journey, he reproduces the idea of the "vanishing race" and is much less concerned with their genocide (that would implicate British settlers) than the institution of slavery that is now framed as an exclusively US-American aberration (cf. AN 184).

21 . This fairly unoriginal ending however is succeeded by the mentioned chapter on slavery and the postscript which somewhat complicates its conciliatory impulse.

22. Daniel Hack argues that "Bleak House does not merely fail to imagine a community that includes Africans, African Americans, slaves, and people of color in general but rather consolidates the national community it does 
imagine by means of their exclusion" (2008: 731). Nevertheless, disregarding this parochial outlook, Hack also shows that African American print culture appropriated the novel for its own cause which he describes intriguingly as the "African Americanization" of Bleak House, most notably as a prominent intertext of Hannah Crafts's The Bondwoman's Narrative (2002 [1853]).

23. Carens argues that missionary zeal in the nineteenth century is tied to the earlier abolitionist campaign and the idea of brotherly connection. Both Evangelical missionaries and evolutionary theorists acknowledged kinship ties between humans "asserting the existence of a universal family" but also preserved "a sense of English superiority" (2005: 31). For Carens, this familiarity with the colonial Other gives rise to the Victorian "repressed fear that colonial 'otherness' dwells within the English state and culture" (2005: 47).

24. This also demonstrates the ongoing precarious relationship between Blackness and femininity which are often construed as mutually exclusive. This can be seen in Seacole's strategic "over-performing" of femininity as well.

25. The overall happy ending of the novel, too, rests to a large degree on Esther's successful domesticity that is firmly grounded in separate gendered spheres and promotes an uplifting service to those within her social circle, leaving the urban squalor behind her. Carens writes, "Esther and Woodcourt begin their married life in the strangely duplicated second Bleak House, an offshoot settlement of the home established by John Jarndyce. This 'colony,' unlike Borriboola-Gha, extends the circle of a middle-class, domestic civilization within the nation and reinforces rather than subverts traditionally gendered spheres of influence. [...] Esther extends the circle of civilization by ensuring that the young women who come under her benign supervision find a secure position within a domestic sphere of a suitable class" (2005: 115).

26. For a Foucauldian study of the Victorian ideology of domesticity in Dickens's fiction, cf. Waters (1997). For a psychoanalytical perspective on family ties in his writing, cf. Lynn Cain who emphasises Dickens's reliance on domesticity: "Despite the panoramic scope of many of the later novels, Dickens is fundamentally a domestic novelist in that his narratives always centre on specific family relationships" (2008: 1).

27. The right kind of familial philanthropy is also an answer to a potentially unruly working class that might take measures into their own hands (cf. Christianson 2007: 98). While Dickens wants a familiar version of reform, he is sceptical of regulation (and his autobiographical experience with debt prison is often cited as a case in point). Cf. Robbins (1990) for a Foucauldian reading of Bleak House that highlights this aspect. 
28. Chennells (cf. 2000: 161-164) discusses Allan Woodcourt's journey to China as an example of such a re-centring of London and masculinity. Woodcourt has to realise the "savageness" of the foreign objects of his philanthropic sympathy during his shipwreck only to heroically return to London and mourn the domestic neglect of Jo.

29. McLaughlin (cf. 1993: 877) discusses this theme of dangerous intimacy. So, while there should be sympathy, middle-class domesticity requires the clean safety of the home as opposed to the dirty streets of London.

30. Seacole seems to become more and more relevant as a fictional character rather than as an author in her own right. There is a reference to Seacole in Salman Rushdie's The Satanic Verses (1988) and she also appears as a fictional character in Bernardine Evaristo's Soul Tourists (2005). Apparently, there is also a film based on her life in the making.

31. Rupprecht cautions that "the textual incursions made by the multiple authorising documents, references to an editor, and the necessity of a legitimising preface, all signal the dangers of conferring upon Seacole an entirely autonomous authorial voice" (2006: 199). I interpret this less as a weakening of her authorial position than as an expression of her narrative dialogical strategy.

32. In an instance when she thinks about the possibility of a many-legged pig, the comparison to the many-headed Hydra is marked as an addendum of her editor. Seacole writes, this was "as my editor tells me somebody called the Hydra (with whom my readers are perhaps more familiar than I am)" (WA 105).

33. Sandra Pouchet Paquet writes disapprovingly, "Seacole seeks English recognition and courts English approval" (1992: 652), others stress the "hybrid" or "liminal" process of identification (cf. Baggett 2000; Cooper 1996: 208; Silku 2008), a notion of "exile" (McKenna 1997), or "mobile subjectivity" (Fish 1997: 477).

34. Jessica Howell speaks of the book's "straight-forward, sincere tone". For her, Seacole's "strategies of self-portrayal" are meant to ensure that "the white subjects in her books [sic] feel familiar and comfortable with her" (2010: 108-109).

35. Hawthorne (2000: 315) argues that the "I was born" beginning is a connection to the genre of the slave narrative rather than the war memoir (cf. also Birkle 2009: 107). However, one can also detect a link to the idealised homo economicus Robinson Crusoe whose fictional autobiography after all also begins with the words "I was born". In this way, Seacole's account is also embedded in the mercantilist tradition of the self-made man/woman (cf. Chap. 2).

36. Similar to Wedderburn, Seacole's white Scottish father becomes instrumental in her notion of British familiality. But while Wedderburn 
includes his struggles with this familiality in his narrative, explicitly trying to partake in the Wedderburn estate while simultaneously publicly calling out his family's involvement in enslavement, as discussed in the previous chapter, Seacole's father like her husband marks a conspicuous absence in the text. McMahon argues, "Neatly raising and then avoiding issues of racial ambiguity, intermarriage, and miscegenation, Seacole's self-description depends upon the presence and erasure of a white father who literally embodies her claim to Britishness, but whose influence is so absolutely undescribed that he seems more like a necessary precondition of her narrative legitimacy than an active component of it" (2008: 185). There is also speculation that Seacole might have had an illegitimate daughter, Sally, after her husband's death who, out of apparent motives, is not mentioned in her text at all (cf. Ramdin 2005; Rappaport 2005; also Gunning 2001: 956; Fluhr 2006: 96). In her biography, Jane Robinson surmises that Sally would have been a relative and not an actual daughter of Seacole (2005: 145).

37. Dallmann similarly argues, "By evoking an American Other, Seacole's narrative constructs a British 'us' which includes the colonial subject" (2012: 439).

38. Gunning elaborates that Seacole seems to disapprove of American chattel slavery but is critical of West Indian ex-slaves. She thereby acknowledges British abolitionist sentiment while catering to racist stereotypes about the "laziness" of the formerly enslaved who now threaten the dominance of the British West Indian planter class (cf. 2001: 966). At times, she derides the natives in Cruces and at other times she praises the freed slaves in New Granada (cf. Om 2014: 88).

39. This simultaneity of various states of freedom and unfreedom for racialised subjects in Central America at the time is apparent in another episode in Gorgona when Seacole recounts with great satisfaction how a young US American woman who chastised her female slave is ordered before the magistrate, "himself a man of colour", and sentenced to set the young woman free (cf. WA 52-53).

40. According to editor Salih, this possibly refers to George Sand (cf. WA 190).

41. Already in 1996 Simon Gikandi cautions no to conceptualise women as outsiders to colonial endeavours and speaks of "imperial femininity" (1996: 119-156).

42. Cf. Birkle (2009) and Fluhr (2006) for more elaborate discussions of the contrast between Nightingale and Seacole. While Seacole strategically does not discredit Nightingale, "that Englishwoman whose name shall never die" (WA 82), it is obvious that Nightingale did not accept Seacole as her equal. In a letter to her brother-in-law, she calls Seacole's British Hotel not " "a bad house' but something not very unlike it" and complains that she "had the greatest difficulty in repelling Mrs Seacole's advances" (quoted in 
Appendix in WA 180). "Bad house" alludes to probable sexual and other improprieties potentially exacerbated by Seacole's racialisation. Seacole, in turn, goes to great lengths to emphasise that neither drunkenness nor dirt were ever tolerated in her hotel (cf. WA 126).

43. Seacole frequently cites letters from soldiers that open with "My Dear Mamma" (WA 112) and those who have been in the West Indies address her as "Mami" (WA 141).

44. In contrast to the emphasis on contagious diseases in Bleak House threatening middle-class femininity, Seacole praises her strong constitution that turns her into an ideal nurse. Howell (2010) reads this as Seacole's valorisation of a specific mixed-race hybrid subjectivity.

45. Cf. Gautam Chakravarty's (2005) study of so-called Mutiny novels for a detailed discussion of literary responses to the events of 1857 .

46. Enticed by sensationalist writing about British women and children being killed in the massacre at Cawnpore, Dickens calls for what could be conceived of as "genocidal attitudes" (Brantlinger 1988: 126) in a letter to Angela Burdett-Coutts in 1857. Earlier Dickens had also infamously replicated racist ideas in his essay "The Noble Savage" in his journal Household Words (cf. Dickens 1853; Poon 2008: 105-109). While Moore states that she is not interested in probing Dickens's political views, it is obvious that, for her, Dickens's final publications stand in contrast to the more public racist outbursts in the 1850s which she considers "erratic" (2004: 131). This however appears strangely apologetic. Dickens later joins his mentor Thomas Carlyle to support Governor John Eyre, who had violently suppressed the Morant Bay Rebellion in Jamaica in 1865, despite calls that he be held responsible for the killing of almost five hundred insurgents. Moore argues Dickens's support for Eyre had "only [...] extended to a signature on a petition" (2004: 164). The infamous letter to W.W.F. de Cerjat, which she quotes in its entirety, does not amount to full-fledged racism because "compared to his previous calls for vengeance, one can see that it [his language] has become comparatively moderate" (2004: 165). The passage regarding Jamaica reads: "The Jamaican insurrection is another hopeful piece of business. That platform-sympathy with the black —or the native, or the devil—afar off, and that platform indifference to our own countrymen at enormous odds in the midst of bloodshed and savagery, makes me stark wild. Only the other day, here was a meeting of jawbones of asses at Manchester, to censure the Jamaica Governor for his manner of putting down the insurrection! So we are badgered about New Zealanders and Hottentots, as if they were identical with men in clean shirts at Camberwell and were bound by pen and ink accordingly" (Dickens 2011: 590-591). Moreover, visiting the United States for a second time in 1868 after the Civil War, Dickens continues to replicate Social Darwinist 
ideas of white supremacy (cf. Taylor 2002: 97, 190). Moore herself concludes, "The racialized discourse that he adopted clearly displays a growing belief in the inferiority of non-white races that was never to leave him" but following this assessment immediately notes that Dickens "was far from being a systematic racist" (2004: 131) and continues to defend comments like those in the letter as "sporadic outbursts of prejudice against nonwhites" and "knee-jerk reactions, grounded in the rhetoric of scientific racism, but lacking the force of a coherent argument" (2004: 166). This appears a more than puzzling conclusion to say the least. As becomes apparent time and again, supporting abolition and replicating racist modes of thinking was not a contradiction at all, especially with the rise of nineteenth-century scientific racism.

47. This nostalgia, Booker posits, is related to the theatricality of the Raj with its lavish visual displays of colonial might that gain relevance after the Mutiny (cf. Booker 1997: 171). I have discussed the role of photography for the colonial spectacle of white masculinity elsewhere at greater length, cf. Haschemi Yekani (2011: 78-105).

48. In another episode, Haitian royalty arrives in Jamaica and King Soulouque and his entourage wish to take up lodgings in Seacole's sister's hotel which she declines on account of what Trollope describes as the "contempt which the coloured people have for negroes": "But the patriotic sister of Mrs. Seacole would listen to no such proposition. 'I won't keep a house for black men,' she said to me. 'As for kings, I would despise myself to have a black king. As for that black beast and his black women-Bah!' Now this was certainly magnanimous, for Soulouque would have been prepared to pay well for his accommodation. But the ordinary contempt which the coloured people have for negroes was heightened in this case by the presumption of black royalty - perhaps also by loyalty. 'Queen Victoria is my king,' said Mrs. Seacole's sister” (Trollope 1859: 117). Instead of an assumed loyalty based on race, Seacole's sister emphasises her Royalist sentiment in an interesting gendering of the Queen. The Creole Seacole expresses her British patriotism by demeaning Black men and bestowing Queen Victoria honorary masculinity.

49. There now exists a statue of Mary Seacole, believed to be the first memorial statue of a Black woman by name in Britain, which was created by sculptor Martin Jennings. It is located opposite the Houses of Parliament in the grounds of St Thomas' Hospital. Cf. https://www. bbc.com/news/uk-england-london-36663206 (accessed 18 September 2019). This form of public commemoration has caused some controversy as the Nightingale Society strongly opposes the supposed "pioneer" status of Seacole and her contribution to the nursing profession which seems to be a contemporary symptom of their ongoing rivalry. Cf. 
http://nightingalesociety.com/category/misinformation/statue/ (accessed 18 September 2019). This again demonstrates the political tension around who can embody national "excellence".

50. Cf. http://news.bbc.co.uk/2/hi/uk_news/3475445.stm (accessed 22 January 2012).

\section{Works Cited}

Ahmed, Sara. 2010. Creating Disturbance. Feminism, Happiness and Affective Differences. In Working with Affect in Feminist Readings. Disturbing Differences, ed. Marianne Liljeström and Susanna Paasonen, 31-44. London: Routledge.

Baggett, Paul. 2000. Caught between Homes: Mary Seacole and the Question of Cultural Identity. MaComère 3: 45-56.

Bhabha, Homi K. 1994. The Location of Culture. London: Routledge.

Birkle, Carmen. 2009. Traveling Nurses: Mary Seacole and the Nightingale Encounter. A Transatlantic Story. In "The Sea is History". Exploring the Atlantic, ed. Carmen Birkle and Nicole Waller, 99-122. Heidelberg: Winter.

Booker, M. Keith. 1997. Colonial Power, Colonial Texts. India in the Modern British Novel. Ann Arbor: University of Michigan Press.

Brantlinger, Patrick. 1988. Rule of Darkness. British Literature and Imperialism, 1830-1914. Ithaca: Cornell University Press.

Brattin, Joel J. 2015. Slavery in Dickens's Manuscript of American Notes for General Circulation. In Dickens and Massachusetts: The Lasting Legacy of the Commonwealth Visits, ed. Diana C. Archibald and Joel J. Brattin, 147-162. Amherst: University of Massachusetts Press.

Brown, Christopher Leslie. 2006. Moral Capital. Foundations of British Abolitionism. Chapel Hill: University of North Carolina Press.

Cain, Lynn. 2008. Dickens, Family, Authorship, Psychoanalytic Perspectives on Kinship and Creativity. Aldershot: Ashgate.

Carens, Timothy. 2005. Outlandish English Subjects in the Victorian Domestic Novel. Basingstoke: Palgrave Macmillan.

- 2008. Bleak House, Africa, and the Condition of England. In Approaches to Teaching Dickens's Bleak House, ed. John O. Jordan and Gordon Bigelow, 38-44. New York: Modern Language Association of America.

Chakravarty, Gautam. 2005. The Indian Mutiny and the British Imagination. Cambridge: Cambridge University Press.

Chennells, Anthony. 2000. Savages and Settlers in Dickens. Reading Multiple Centres. In Dickens and the Children of Empire, ed. Wendy S. Jacobson, 153-172. Houndmills: Palgrave.

Christianson, Frank. 2007. Philanthropy in British and American Fiction-Dickens, Hawthorne, Eliot and Howells. Edinburgh: Edinburgh University Press. 
Claybaugh, Amanda. 2006. Toward a New Transatlanticism: Dickens in the United States. Victorian Studies 48 (3): 439-460.

- 2007. The Novel of Purpose: Literature and Social Reform in the AngloAmerican World. Ithaca: Cornell University Press.

Cooper, Helen M. 1996. "Tracing the Route to England": Nineteenth-Century Caribbean Interventions into English Debates on Race and Slavery. In The Victorians and Race, ed. Shearer West, 194-212. Aldershot: Scolar Press.

Crafts, Hannah. 2002 [1853]. The Bondwoman's Narrative. Ed. Henry Louis Gates. New York: Warner Books.

Cvetkovich, Ann. 1992. Mixed Feelings. Feminism, Mass Culture, and Victorian Sensationalism. New Brunswick: Rutgers University Press.

Dallmann, Antje. 2012. To "the General Reformation of American Manners": Popular Icons, Transnational Nursing Narratives, and the (Medical) Gaze Returned in Wonderful Adventures of Mrs. Seacole in Many Lands (1857). In Transnational American Studies, ed. Udo J. Hebel, 423-444. Heidelberg: Winter.

Dickens, Charles. 1853. The Noble Savage. Household Words 7 (15): 337-339.

- 2000 [1842]. American Notes for General Circulation. Ed. Patricia Ingham. London: Penguin.

- 2003 [1852-1853]. Bleak House. Ed. Nicola Bradbury. London: Penguin.

- 2011. Letters of Charles Dickens: 1833-1870. Eds. Georgina Hogarth and Mary Dickens. Cambridge: Cambridge University Press.

Dietze, Gabriele. 2013. Weiße Frauen in Bewegung. Genealogien und Konkurrenzen von Race-und Genderpolitiken. Bielefeld: transcript.

Evaristo, Bernardine. 2005. Soul Tourists. London: Penguin.

Fabi, M. Giulia. 1997. Representing Slavery in Nineteenth-Century Britain: The Anxiety of Non/Fictional Authorship in Charles Dickens' American Notes (1842) and William Brown's Clotel (1853). In Images of America: Through the European Looking-Glass, ed. William L. Chew III, 125-140. Brussels: VUB University Press.

Fish, Cheryl. 1997. Voices of Restless (Dis)continuity: The Significance of Travel for Free Black Women in the Antebellum Americas. Women's Studies 26 (5): 475-495.

Flint, Kate. 2000. Dickens and the Native American. In Dickens and the Children of Empire, ed. Wendy S. Jacobson, 94-104. Houndmills: Palgrave.

Fluhr, Nicole. 2006. “Their Calling Me 'Mother' Was Not, I Think, Altogether Unmeaning”: Mary Seacole's Maternal Personae. Victorian Literature and Culture 34 (1): 95-113.

Gikandi, Simon. 1996. Maps of Englishness. Writing Identity in the Culture of Colonialism. New York: Columbia University Press. 
Green, Martin. 1980. Dreams of Adventure, Deeds of Empire. London: Routledge \& Kegan Paul.

Gunning, Sandra. 2001. Traveling with Her Mother's Tastes: The Negotiation of Gender, Race, and Location in Wonderful Adventures of Mrs. Seacole in Many Lands. Signs 26 (4): 949-981.

Hack, Daniel. 2008. Close Reading at a Distance: The African Americanization of Bleak House. Critical Inquiry 34 (4): 729-753.

Haschemi Yekani, Elahe. 2011. The Privilege of Crisis. Narratives of Masculinities in Colonial and Postcolonial Literature, Photography and Film. Frankfurt am Main: Campus.

Hawthorne, Evelyn J. 2000. Self-Writing, Literary Traditions, and PostEmancipation Identity: The Case of Mary Seacole. Biography 23 (2): 309-331.

Howell, Jessica. 2010. Mrs. Seacole Prescribes Hybridity: Constitutional and Maternal Rhetoric in Wonderful Adventures of Mrs. Seacole in Many Lands. Victorian Literature and Culture 38 (1): 107-125.

Innes, C. Lyn. 2002. A History of Black and Asian Writing in Britain 1700-2000. Cambridge: Cambridge University Press.

Makdisi, Saree. 2014. Making England Western. Occidentalism, Race, and Imperial Culture. Chicago: University of Chicago Press.

McKenna, Bernard. 1997. "Fancies of Exclusive Possession": Validation and Dissociation in Mary Seacole's England and Caribbean. Philological Quarterly 76 (2): 219-239.

McLaughlin, Kevin. 1993. Losing One's Place: Displacement and Domesticity in Dickens's Bleak House. MLN 108 (5): 875-890.

McMahon, Deirdre H. 2008. 'My Own Dear Sons': Discursive Maternity and Proper British Bodies in Wonderful Adventures of Mrs. Seacole in Many Lands. In Other Mothers: Beyond the Maternal Ideal, ed. Ellen Bayuk Rosenman and Claudia C. Klaver, 181-201. Columbus: Ohio State University Press.

Miller, D.A. 1983. Discipline in Different Voices: Bureaucracy, Police, Family, and Bleak House. Representations 1: 59-89.

Moore, Grace. 2004. Dickens and Empire. Discourses of Class, Race and Colonialism in the Works of Charles Dickens. Aldershot: Ashgate.

Mulvey, Christopher. 1990. Transatlantic Manners. Social Patterns in NineteenthCentury Anglo-American Travel Literature. Cambridge: Cambridge University Press.

Om, Donghee. 2014. From the Black Sea to the Black Atlantic: Blackness and Performativity in The Wonderful Adventures of Mrs. Seacole in Many Lands. Victorians: A Journal of Culture and Literature 125: 76-100.

Paquet, Sandra Pouchet. 1992. The Enigma of Arrival: The Wonderful Adventures of Mrs. Seacole in Many Lands. African American Review 26 (4): 651-663. 
Paravisini-Gebert, Lizabeth. 2003. Mrs Seacole's Wonderful Adventures in Many Lands and the Consciousness of Transit. In Black Victorians/Black Victoriana, ed. Gretchen Holbrook Gerzina, 71-87. New Brunswick: Rutgers University Press.

Poon, Angelia. 2008. Enacting Englishness in the Victorian Period. Colonialism and the Politics of Performance. Aldershot: Ashgate.

Purton, Valerie. 2012. Dickens and the Sentimental Tradition. Fielding, Richardson, Sterne, Goldsmith, Sheridan, Lamb. London: Anthem Press.

Ramdin, Ron. 2005. Mary Seacole. London: Haus.

Rappaport, Helen. 2005. The Invitation that Never Came: Mary Seacole after the Crimea. History Today 55 (2): 9-15.

Robbins, Bruce. 1990. Telescopic Philanthropy: Professionalism and Responsibility in Bleak House. In Nation and Narration, ed. Homi K. Bhabha, 213-230. London: Routledge.

Robinson, Amy. 1994. Authority and the Public Display of Identity: Wonderful Adventures of Mrs. Seacole in Many Lands. Feminist Studies 20 (3): 537-557.

Robinson, Jane. 2005. Mary Seacole: The Charismatic Black Nurse Who Became a Heroine of the Crimea. London: Constable \& Robinson.

Romero-Cesareo, Ivette. 2001. Women Adrift: Madwomen, Matriarchs, and the Caribbean. In Women at Sea: Travel Writing and the Margins of Caribbean Discourse, ed. Lizabeth Paravisini-Gebert and Ivette Romero-Cesareo, 135-160. New York: Palgrave.

Rupprecht, Anita. 2006. Wonderful Adventures of Mrs Seacole in Many Lands (1857): Colonial Identity and the Geographical Imagination. In Colonial Lives across the British Empire. Imperial Careering in the Long Nineteenth Century, ed. David Lambert and Alan Lester, 176-203. Cambridge: Cambridge University Press.

Rushdie, Salman. 1988. The Satanic Verses. London: Viking.

Salih, Sara. 2004. "A gallant heart to the empire." Autoethnography and Imperial Identity in Mary Seacole's Wonderful Adventures. Philological Quarterly 83 (2): 171-195.

Seacole, Mary. 2005 [1857]. Wonderful Adventures of Mrs Seacole in Many Lands. Ed. Sara Salih. London: Penguin.

Silku, Rezzan Kocaoner. 2008. Wonderful Adventures. Transcending Liminality and Redefining Identity in Mary Jane Grant Seacole's Autobiography. Ariel 39 (1-2): 113-127.

Stowe, Harriet Beecher. 1981 [1852]. Uncle Tom's Cabin, or, Life among the Lowly. Ed. Ann Douglas. Harmondsworth: Penguin.

Swaminathan, Srividhya. 2009. Debating the Slave Trade. Rhetoric of British National Identity, 1759-1815. Farnham: Ashgate.

Taylor, Jonathan. 2002. Mastery and Slavery in Victorian Writing. New York: Palgrave Macmillan. 
Teukolsky, Rachel. 2009. Pictures in Bleak Houses: Slavery and the Aesthetics of Transatlantic Reform. ELH 76 (2): 491-522.

Trollope, Anthony. 1859. The West Indies and the Spanish Main. London: Chapman \& Hall.

Waters, Catherine. 1997. Dickens and the Politics of the Family. Cambridge: Cambridge University Press.

Yousef, Nancy. 2009. The Poverty of Charity: Dickensian Sympathy. In Contemporary Dickens, ed. Eileen Gillooly and Deirdre David, 53-74. Columbus: Ohio State University Press.

Open Access This chapter is licensed under the terms of the Creative Commons Attribution 4.0 International License (http://creativecommons.org/licenses/ by $/ 4.0 /$ ), which permits use, sharing, adaptation, distribution and reproduction in any medium or format, as long as you give appropriate credit to the original author(s) and the source, provide a link to the Creative Commons licence and indicate if changes were made.

The images or other third party material in this chapter are included in the chapter's Creative Commons licence, unless indicated otherwise in a credit line to the material. If material is not included in the chapter's Creative Commons licence and your intended use is not permitted by statutory regulation or exceeds the permitted use, you will need to obtain permission directly from the copyright holder.

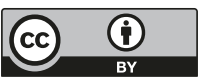

